\title{
Glacial activity and catchment dynamics in northwest Greece: Long-term river behaviour and the slackwater sediment record for the last glacial to interglacial transition ${ }^{\text {t3 }}$
}

\author{
J.C. Woodward ${ }^{\text {a,* }}$, R.H.B. Hamlin ${ }^{\text {b }}$, M.G. Macklin ${ }^{\text {c }}$, P.D. Hughes ${ }^{\text {a }}$, J. Lewin ${ }^{\text {c }}$ \\ a Geography, School of Environment and Development, The University of Manchester, Manchester, M13 9PL, UK \\ b School of Geography, University of Leeds, Leeds, LS2 9JT, UK \\ c Centre for Catchment and Coastal Research, Institute of Geography and Earth Sciences, Aberystwyth University, Penglais, Aberystwyth, Ceredigion SY23 3DB, UK
}

\section{A R T I C L E I N F O}

Article History:

Accepted 25 April 2008

Available online 25 May 2008

\section{Keywords:}

Mediterranean

Glaciation

Pleistocene climate change

River dynamics

Slackwater sediments

Sediment sources

\begin{abstract}
A B S T R A C T
Pleistocene glacial activity transformed the runoff regimes and sediment loads of many river systems in the Mediterranean region. New data from northwest Greece show marked contrasts in ice volume and extent between cold stages of the Middle and Late Pleistocene. These altered the long-term meltwater routes and sediment supply conditions in glaciated river catchments. The Voidomatis River basin $\left(384 \mathrm{~km}^{2}\right)$ of northwest Greece now contains one of the best dated records of Middle and Late Pleistocene glacial and fluvial activity that is constrained by over 40 radiometric dates. This paper evaluates the glacial and fluvial geomorphological records to establish a series of correlations and to produce a fuller picture of Middle and Late Pleistocene landscape dynamics in a glaciated Mediterranean catchment. We propose a model of longterm river response to headwater glaciation for the Voidomatis River basin that may have some broader significance for mountain catchments in the Mediterranean and elsewhere. The transfer and storage of coarse-grained river sediment during the Late Pleistocene was strongly conditioned by the major Middle Pleistocene glaciations of MIS 12 and MIS 6. Glaciers were much smaller during the last cold stage (MIS 5d to 2), but meltwater floods still dominated suspended sediment fluxes throughout this period. Uniquely, the Voidomatis River basin contains fine-grained slackwater sediments that record the transition from glacial to interglacial conditions in the Mediterranean region at the end of the last cold stage. Sediment source data from the slackwater deposits record a relatively rapid reorganisation of the hydrology and sediment supply conditions in the catchment between about 20 and $17 \mathrm{ka}$. These deposits have allowed us to explore flood history and the dynamics of suspended sediment sources during this period for the first time. The use of quantitative sediment fingerprinting in palaeoflood studies has yielded a new understanding of long-term catchment dynamics that has not hitherto been attainable using conventional techniques.
\end{abstract}

(c) 2008 Elsevier B.V. All rights reserved.

\section{Introduction}

Recent work has shown that river systems across the Mediterranean were highly responsive to climatically-driven fluctuations in sediment supply during the Middle and Late Pleistocene. Macklin et al. (2002) have analysed the alluvial stratigraphic records and dating frameworks for river basins across the region and have shown that, for at least the last $200 \mathrm{ka}$ or so, major phases of river aggradation have coincided with periods of cooler climate associated with increases in sediment supply from hillslopes to river channels. Conversely, during episodes of warmer climate, reduced rates of bedrock weathering coupled with increases in catchment vegetation cover resulted in a net

\footnotetext{
is Paper presented at the 39th Binghamton Geomorphology Symposium, Austin, Texas, October 2008.

* Corresponding author.

E-mail address: jamie.woodward@man.ac.uk (J.C. Woodward).
}

decline in river sediment loads forcing trunk streams across the region to incise into valley floors (e.g. Fuller et al., 1998).

Pleistocene glaciers in Mediterranean latitudes were especially sensitive to these changes in climate. Furthermore, major changes in the mass balance characteristics of these glaciers impacted significantly on water and sediment fluxes from headwater terrains to downstream river channel networks. New data from the Mediterranean mountains has shown that very significant contrasts were evident in the extent and volume of glacier ice between cold stages of the Middle and Late Pleistocene (Kotarba et al., 2001; Giraudi, 2003; Hughes et al., 2006a). The long-term dynamics of Mediterranean glaciers would have exerted an important influence on the geomorphology of river channel systems downstream by, for example, enhancing flood magnitude and sediment supply during major meltwater events. In many cases, this influence extended to low elevation reaches below $500 \mathrm{~m}$ and even to the coastal zone.

Although it has been known for well over a century that many of the high mountains in the Mediterranean were glaciated during the 
Pleistocene (Messerli, 1967; Smith et al., 1997; Woodward et al., 2004; Hughes et al., 2006b; Hughes and Woodward, in press), most welldated records of long long-term river behaviour in the region come from river basins that were not directly influenced by glacial activity (Lewin et al., 1995; Fuller et al., 1998; Rose and Meng, 1999; Kelly et al., 2000; Macklin et al., 2002; Schulte et al., in press; Macklin and Woodward, in press). This paper synthesises three phases of research conducted over the past two decades in the Voidomatis River basin of northwest Greece and presents a new correlation of the glacial and fluvial records in the catchment. This analysis is possible because the basin now contains one of the best dated and well documented records of Middle and Late Pleistocene glacial and fluvial activity. It therefore provides an unrivalled opportunity to explore long-term interactions between these two key components of the geomorphology of the Mediterranean mountains. The record of long-term river behaviour is based on a multi-method geochronology for a series of coarse-grained alluvial units that are well preserved in the middle and lower reaches of the Voidomatis River basin. The glacial record on Mount Tymphi in the limestone headwaters of the Voidomatis is constrained by 28 uranium-series ages on secondary calcite deposits in glacial sediments. The lower reaches of the catchment also contain fine-grained slackwater deposits (SWDs) that, uniquely, record the transition from the full glacial conditions of the last cold stage to postglacial conditions in this part of the Mediterranean. Systematic analysis of these deposits, using quantitative sediment sourcing methods (Walling and Woodward, 1995; Collins et al., 1997), has permitted the first examination of flood history and suspended sediment source dynamics during this key period of global change.

\section{Background and aims}

Research into Pleistocene and Holocene river behaviour in the Voidomatis basin began in the mid 1980s. This formed part of the offsite investigations associated with the interdisciplinary exploration of Upper Palaeolithic human activity in northwest Greece centred on Klithi rockshelter (Bailey, 1997a,b; Woodward, 1997a,b; Woodward and Bailey, 2000). The first phase of fieldwork in the basin focussed on the record of Quaternary river behaviour and led to a series of publications that examined the controls and timing of fluvial sedimentation (Lewin et al., 1991), long-term sediment source dynamics (Woodward et al., 1992), the nature and significance of pedogenic weathering on alluvial terrace surfaces (Woodward et al., 1994), and the relationship between these data and records of Late Upper Palaeolithic settlement and global change (Bailey et al., 1990; Woodward et al., 1995; Macklin et al., 1997). A second phase of fieldwork in the mid 1990s examined the role of large floods in shaping the Pleistocene and Holocene fluvial geomorphology of the basin (Hamlin, 2000; Hamlin et al., 2000) and the Voidomatis SWDs

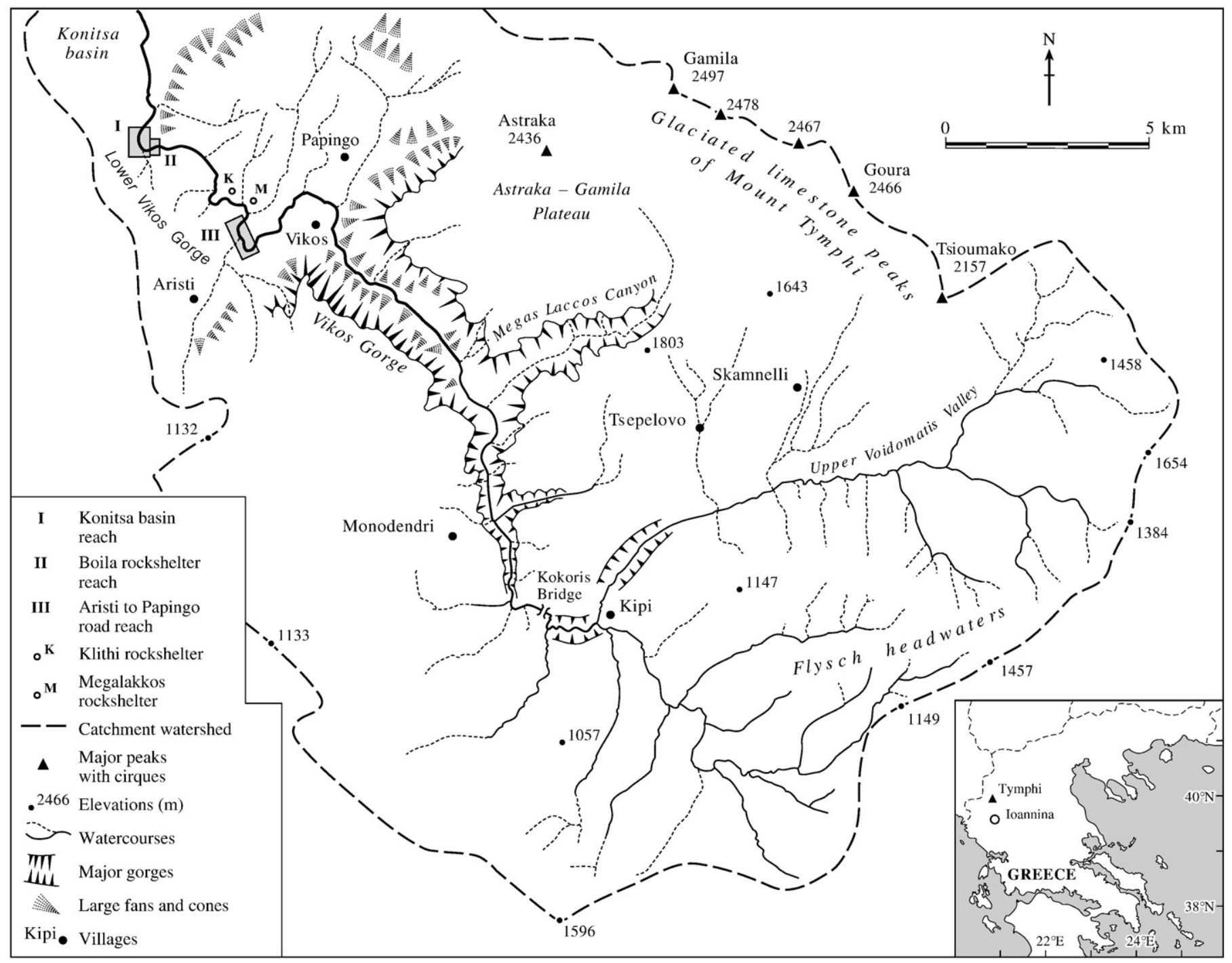

Fig. 1. The Voidomatis River basin and the key sites mentioned in the text. 
were studied in detail for the first time (Hamlin, 2000; Woodward et al., 2001). During this period, work also began on developing a geochronological framework - using uranium-series methods - for the glacial deposits on Mount Tymphi in the headwaters of the Voidomatis River (Woodward et al., 2004) because satellite remote sensing of the glaciated terrains had indicated the presence of extensive glacial moraines representing at least two phases of glacial advance and retreat (Smith et al., 1998, 2000). The most recent phase of fieldwork in the basin began in 2001. This has focussed on the glacial record on the slopes of Mount Tymphi (Fig. 1) to establish the number, extent, age and palaeoclimatic significance of glacial phases in this part of the Pindus Mountains. This work has recently been completed (Hughes et al., 2006a).

This paper draws together the key findings of these projects for the first time and explores their broader geomorphological significance. It has two key aims:

1) To evaluate the glacial and fluvial geomorphological records in the Voidomatis basin and propose a series of correlations to produce a fuller picture of Middle and Late Pleistocene landscape dynamics in a glaciated Mediterranean catchment.

2) To develop previous work on the contrasts in fluvial sediment sources associated with cold stage glacial and interglacial river environments (Woodward et al., 1992; Hamlin et al., 2000) by utilising the high resolution record of flooding provided by the SWDs to examine the behaviour of a glaciated catchment during the transition from glacial to interglacial conditions.

A key objective of (2) is to establish the sediment source signatures associated with individual floods during this climatic transition and to improve our understanding of catchment dynamics during this period of major global change.

\section{The Voidomatis River basin}

The Voidomatis River is a steep-gradient cobble- and boulder-bed stream draining a catchment of approximately $384 \mathrm{~km}^{2}$ in the Pindus Mountains of northwest Greece (Lewin et al., 1991; Bailey et al., 1997). On the northwest flank of the Konitsa basin it joins the Aoos River $\left(665 \mathrm{~km}^{2}\right)$ which drains a larger catchment to the north and east that also includes glaciated upland terrains (Boenzi et al., 1992; Hughes et al., 2006c,d). Much of the Voidomatis basin lies above $1000 \mathrm{~m}$ and the highest peaks of Mount Tymphi exceed $2400 \mathrm{~m}$. The Astraka-
Gamila plateau lies just below the highest peaks and is flanked to the south by the Megas Laccos Canyon and to the southwest by the main Vikos Gorge (Fig. 1). The landscape is dominated by high limestone uplands and by a network of spectacular gorges and ravines in the middle reaches of the Voidomatis catchment (Fig. 2). Three rockshelters (Klithi, Megalakkos and Boila) have been excavated in the Lower Vikos Gorge and each contains Late Pleistocene sediments (Bailey and Woodward, 1997; Woodward, 1997a,b; Woodward and Bailey, 2000) with Late Upper Palaeolithic stone tools and faunal remains (Bailey 1997a; Kotjabopoulou et al., 1999).

The highest parts of the catchment were glaciated during cold stages of the Pleistocene and the glacial geomorphology is very well preserved (Bailey et al., 1990; Lewin et al., 1991; Woodward et al., 2004; Hughes et al., 2006a). The Pleistocene glaciers created a deeply scoured upland glacio-karst landscape (Fig. 3) with a range of glacial landforms. The glacial landscape is especially well developed on the southern slopes of Mount Tymphi across the Astraka-Gamila plateau and in the upland terrain above the villages of Skamnelli and Tsepelovo (Fig. 1) where lateral and terminal moraines form major landscape features. The tills associated with the Mount Tymphi moraines are dominated by glacially-modified limestone materials (>99\% limestone clasts) with large sub-rounded boulders and a distinctive fine-grained matrix derived from glacial comminution of limestone bedrock and limestone clasts (Woodward et al., 1992, 1995; Hughes et al., 2006a,c).

The solid geology of the catchment is dominated by Late Eocene limestones and flysch with some very limited exposures of ophiolite in the eastern headwaters of the catchment (IGME, 1968, 1970). The flysch rocks are well bedded sandstones and siltstones typically associated with steep slopes and relatively high drainage densities. They are important at low elevations and the flysch catchments are extensive upstream of Kipi to the south of the glaciated terrains in the Voidomatis headwaters (Fig. 1). These rocks are also present on either side of the Lower Vikos Gorge where a series of tributary streams transport flysch sediments to the modern Voidomatis channel (Fig. 1) (Bailey et al., 1997). Erosion of the weaker, finer-grained beds of flysch is the major source of fine-grained $(<63 \mu \mathrm{m})$ suspended sediment in the modern river (Woodward et al., 1992; Hamlin, 2000).

The Vikos Gorge, one of the deepest in Europe, has near vertical sides over $800 \mathrm{~m}$ high and exposes Eocene and Jurassic limestones. Outcrops of dolomite are also present (IGME, 1970). The upper reaches of the Vikos Gorge are fed from the north by the Megas Laccos Canyon

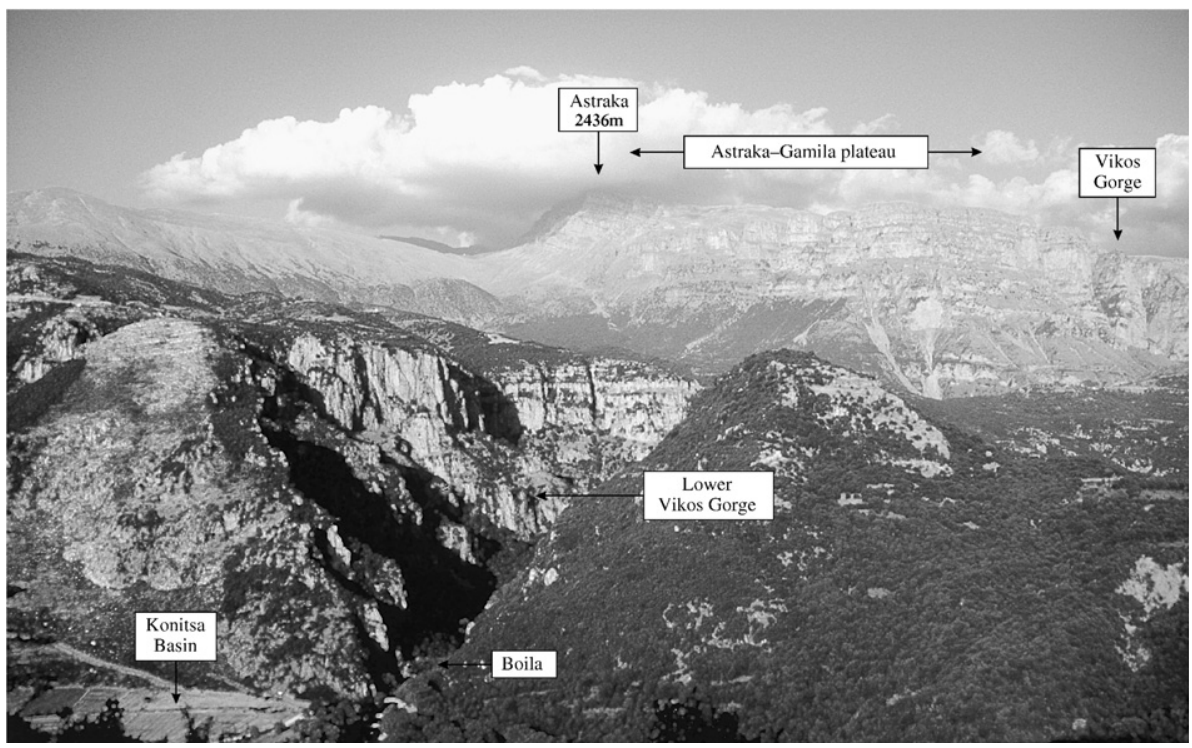

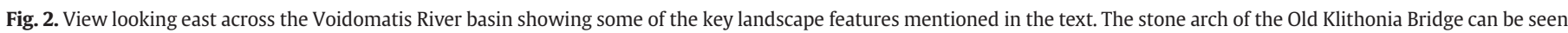
at the end of the Lower Vikos Gorge. Photograph by Jamie Woodward. 


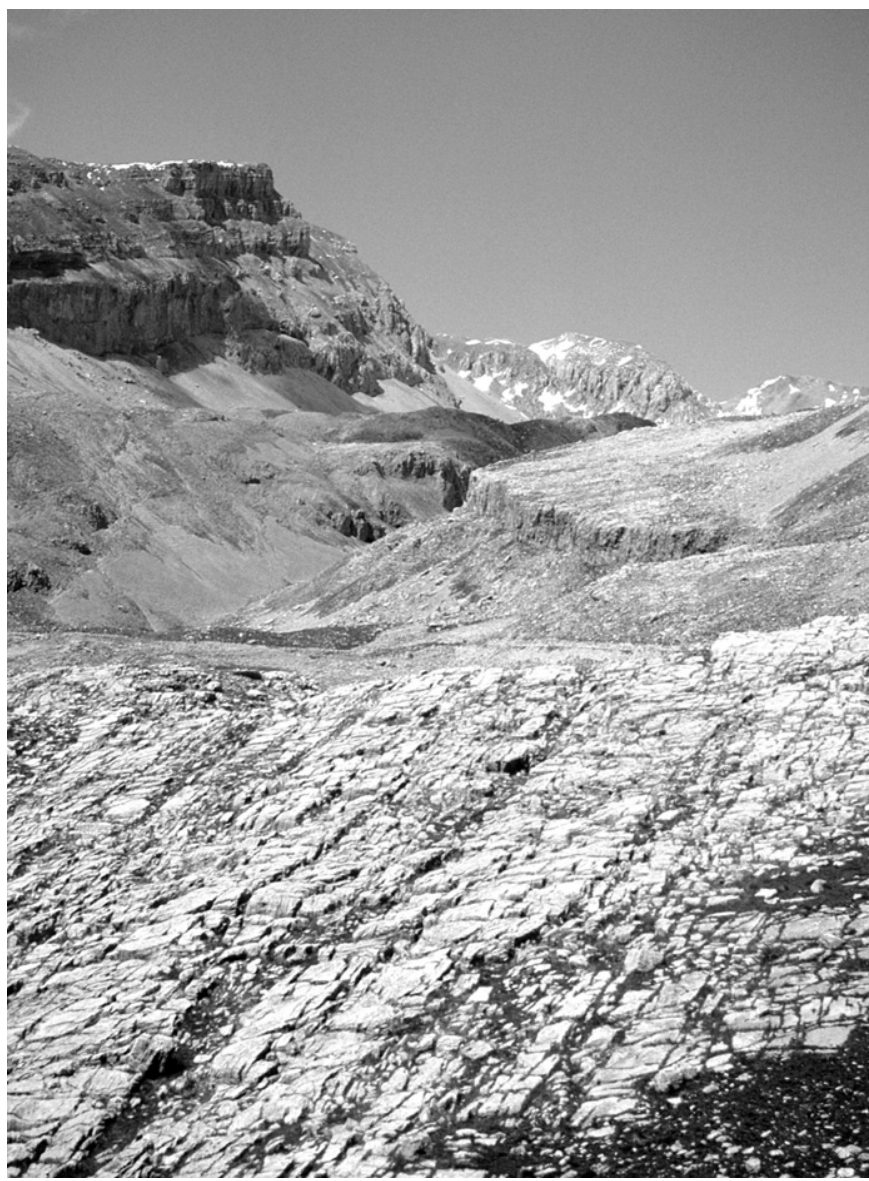

Fig. 3. Glacially-scoured terrain above Tsepelovo and Skamnelli showing steep limestone cliffs, thick scree slopes and extensive limestone pavements. Photograph by Jamie Woodward.

(which drains much of the Astraka-Gamila plateau) and from the east by the Upper Voidomatis Valley upstream of Kipi (Fig. 1). Further downstream the Voidomatis flows through the deeply incised limestone bedrock meanders of the Lower Vikos Gorge before emerging onto the Konitsa basin (Fig. 2). The sides of the Lower Vikos Gorge are cut by a series of steep-gradient tributary ravines draining catchments with eroding flysch headwaters. Coarse-grained terraced alluvial sediments are well preserved in several reaches in the main gorges and in the Konitsa basin in the lower reaches of the catchment (Fig. 1). A detailed account of the geology, geomorphology and vegetation of the Voidomatis basin is given in Bailey et al. (1997).

\section{The Pleistocene glacial record}

During the first phase of geomorphological fieldwork in the Voidomatis basin (1985-1990), a working hypothesis emerged that the glacial sediments and landforms on Mount Tymphi were formed during the last cold stage - although, at this time, no dates were available from the glacial sediments themselves to test this idea (Bailey et al., 1990; Lewin et al., 1991; Woodward et al., 1995). This hypothesis was based on several lines of evidence. First, a major phase of coarse-grained alluvial sedimentation - with very similar lithological characteristics to the glacial sediments - was dated to the end of the last cold stage. This was named the Aristi Unit by Lewin et al. (1991) and it forms a prominent terrace surface in many parts of the basin. From materials exposed in the lower basin just downstream of Boila rockshelter (Fig. 1), the Aristi Unit was dated to c. 28.2 to $24.3 \mathrm{ka}$ on the basis of a TL date and 3 ESR dates (Lewin et al., 1991). Second, lithologically-identical Aristi-type fluvial sediments can be seen in association with glacial deposits where moraines reach the valley floor in the Upper Voidomatis Valley to the south of Tsepelovo (Fig. 1) (Woodward et al., 1995). Thirdly, detailed mapping of the glaciated uplands had not yet been carried out and, in the absence of direct dating evidence from the glacial sequences, the exceptionally wellpreserved glacial deposits and landforms (with many sharp moraine crests and extensive limestone pavements) were indicative of a Late Pleistocene age. This was in good agreement with the conventional wisdom of the 1960s to 1990s for the timing of Mediterranean glaciation (e.g. Messerli, 1967; Palmentola et al., 1990).

Later work that examined the utility of SPOT and TM imagery to map all of the glacial terrain in the catchment indicated that the glaciated landscape on Mount Tymphi comprised deposits of markedly different ages. The satellite imagery showed that strongly weathered moraines existed at lower elevations and fresher and sharper moraines were present in mid-valley positions at higher elevations above the villages of Skamnelli and Tsepelovo (Smith et al., 1998). In the absence of radiometric dating evidence, however, it was still not possible to say with certainty whether these two groups of moraines represented separate glacial advances during the same cold stage or whether they were the product of glacial activity in different cold stages. In 1995, a preliminary assessment of soil development on the most extensive glacial deposits down-valley of Tsepelovo indicated that they were much older than the moraines at higher elevations. Despite the evidence for greater complexity in the glacial record suggested by the satellite imagery and the preliminary soil investigations, without radiometric dates it was still not possible to place the glacial deposits within a robust chronostratigraphic framework.

The first radiometric ages for the glacial deposits on Mount Tymphi were obtained following the second phase of fieldwork in the Voidomatis basin in the late 1990s. Samples of secondary carbonates (calcretes) collected from the till matrix at several exposures on Mount Tymphi yielded nine uranium-series ages which were reported by Woodward et al. (2004). These were the first radiometric dates from glacial deposits in Greece. Significantly, they showed that the earliest glacial deposits on Mount Tymphi had formed before $350 \mathrm{ka}$ and that a later phase of glacial activity took place before the last interglacial. These results forced a radical rethink of the Pleistocene history of the Pindus Mountains (Palmentola et al., 1990) and were contrary to the widely held view that the glacial sequences in Greece and across much of the Mediterranean were formed during the last glacial stage (e.g. Messerli, 1967; Palmentola et al., 1990; Boenzi et al., 1992; Boenzi and Palmentola, 1997).

At this point it became clear that a systematic mapping and uranium-series dating programme was needed to unravel the glacial record on Mount Tymphi and the wider Pindus Mountains. This work has led to a series of papers on the geochronology and stratigraphy (Hughes et al., 2006a) and the palaeoclimatic significance of the glacial record (Hughes et al., 2006d, 2007). This new model is summarised in the following section.

\section{A new glacial stratigraphy}

The glaciated headwater terrains on the slopes of Mount Tymphi have now been mapped in detail and three glacial stages have been identified in the geomorphological and sedimentological records. The glacial sequence on Mount Tymphi is shown in Fig. 4 and the geochronological data are summarised in Table 1. Three glacial stages have been formally defined by Hughes et al. (2006a) and correlated with the long pollen record from Lake Ioannina that lies about $40 \mathrm{~km}$ south of the Voidomatis basin (Fig. 1). The glacial record is based on extensive field mapping of the glacial geomorphology and stratigraphy and systematic examination of pedogenic weathering profiles (including assessment of the profile development index) on the surface of moraines and the most comprehensive programme of 


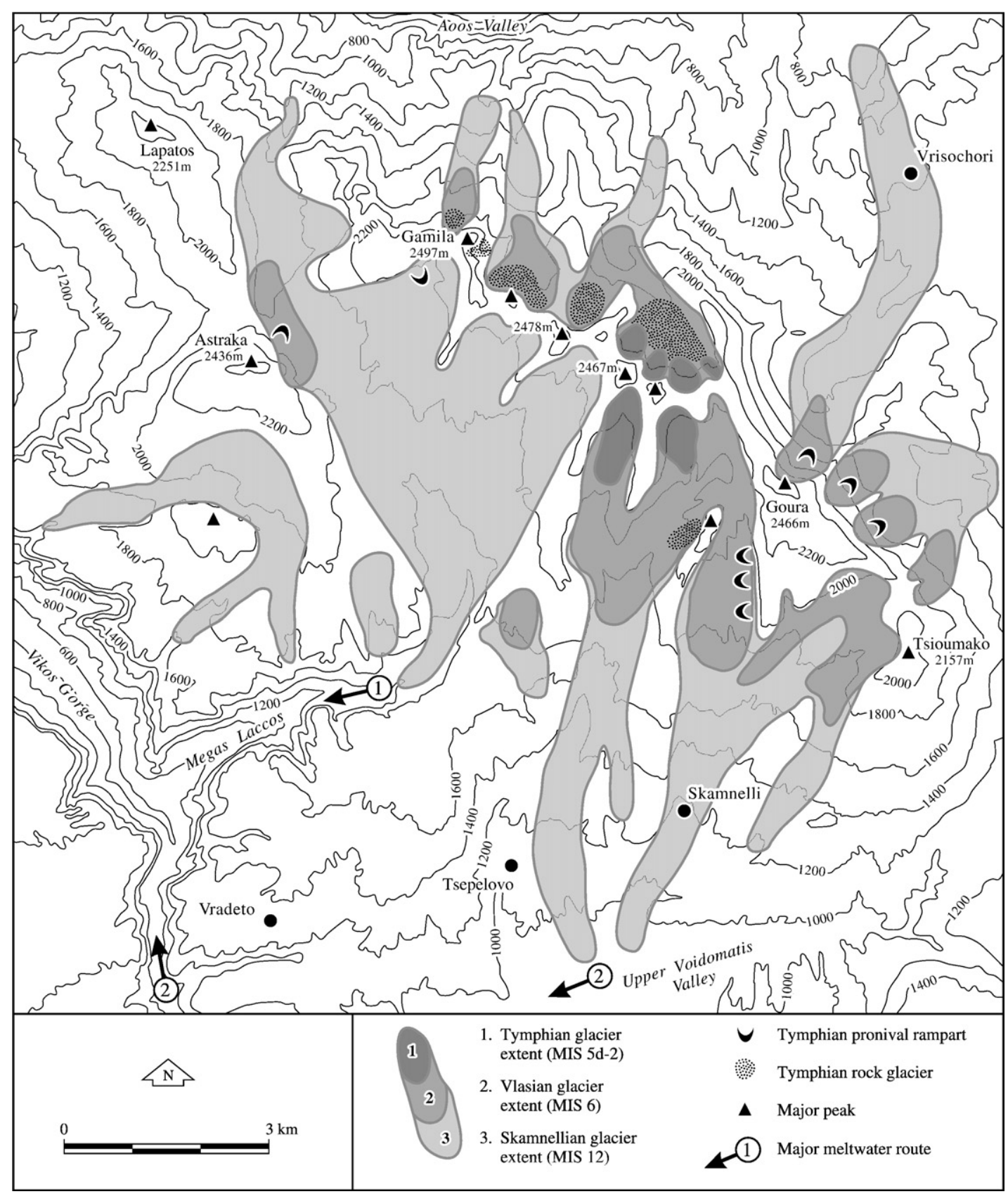

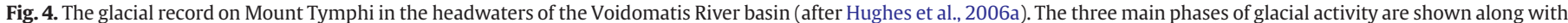
the two main routes for Pleistocene glacial meltwater flux to the Voidomatis fluvial system. All the uranium-series ages for the glacial record are shown in Table 1.

uranium-series dating yet conducted on glacial deposits in the Mediterranean. The glacial stratigraphical framework for the Pindus Mountains is underpinned by 28 uranium-series ages (Table 1 ). The record has been presented in full with a series of geomorphological maps and Equilibrium Line Altitude (ELA) reconstructions in Hughes et al. (2006a, 2007) and is therefore only briefly summarised below.

\subsection{The Skamnellian Stage}

The earliest and most extensive phase of glacial activity predates $350 \mathrm{ka}$ and was characterised by the development of large ice fields and extensive valley glaciers on the southern slopes of Mount Tymphi and across the Astraka-Gamila plateau (Fig. 4). The moraines from this glaciation have deeply weathered soil profiles with profile development indices (PDIs) ranging from 51.8 to 61 (Hughes et al., 2006a). The glaciers extended southwards beyond the villages of Tsepelovo
(1100 $\mathrm{m}$ ) and Skamnelli $(1150 \mathrm{~m})$ down to about $850 \mathrm{~m}$ above sea level (Fig. 4). Here, in the Upper Voidomatis Valley, these glacial deposits are well exposed on the right bank of the modern Voidomatis River (Woodward et al., 1995; Hughes et al., 2006a). At its maximum extent, ice cover during the Skamnellian glaciation approached $60 \mathrm{~km}^{2}$ and the mean ELA was c. $1741 \mathrm{~m}$ above sea level (Hughes et al., 2007). At this time, meltwaters from this large ice mass drained into the middle reaches of the Voidomatis River via the Megas Laccos Canyon from the Astraka-Gamila plateau and surrounding cirques (Fig. 4). A smaller area of ice accumulation has also been mapped on the Astraka-Gamila plateau to the south of the Astraka peak (Fig. 4). This drains directly into the main Vikos Gorge via very steep tributary ravines and at least one of these contains steep fan sediments where it meets the main canyon (Hamlin, 2000). The oldest secondary carbonates from sediments associated with this phase of glaciation are beyond the range of uranium-series dating and 6 samples yielded 
Table 1

The stratigraphy and geochronology for the glacial deposits on Mount Tymphi (after Woodward et al., 2004; Hughes et al., 2006a)

\begin{tabular}{|c|c|c|c|c|}
\hline Stage name & Dated units & Geomorphological characteristics & Age of host glacial units & Soil characteristics \\
\hline & $\begin{array}{l}\text { Uranium-series ages of secondary calcites } \\
\text { in years BP and the corresponding interval } \\
\text { in the marine isotope record }\end{array}$ & & & \\
\hline Tymphian & $\begin{array}{l}\text { No dates because of the absence of } \\
\text { secondary carbonates and organic materials. } \\
\text { These deposits are coarse-grained and clast } \\
\text { supported and contain little or no matrix } \\
\text { available for carbonate dissolution and } \\
\text { reprecipitation }\end{array}$ & $\begin{array}{l}\text { Small cirque moraines and relict rock } \\
\text { glaciers. Lowest elevation of these } \\
\text { features is }>1800 \mathrm{~m} \text { a.s.l. }\end{array}$ & $\begin{array}{l}\text { Geochronology undefined. However, } \\
\text { the cirque moraines were formed by } \\
\text { the last glaciers in Greece. Debris rock } \\
\text { glaciers were sourced from these cirque } \\
\text { moraines and talus rock glaciers formed } \\
\text { in cirques after glacier retreat. These } \\
\text { deposits are correlated with the last glacial } \\
\text { cycle and MIS } 5 d-2 \text { (Weichselian/Würmian) }\end{array}$ & $\begin{array}{l}\text { Profile development } \\
\text { index of } 7.8 \text { to } 9.0\end{array}$ \\
\hline Vlasian & $\begin{array}{l}\text { Vourtapa Member (B2a) } \\
131,250 \pm 19,250 * \text { [MIS 5e/6] } \\
118,450(119,818 \pm 9249) \text { [MIS 5e] } \\
109,116(110,198 \pm 4107) \text { [MIS5e] } \\
81,700 \pm 12,90 *^{*} \text { [MIS 5a] } \\
\text { Vrichos Member (B2b) } \\
80,450 \pm 15,100 * \text { [MIS 5a] } \\
\text { Xeroloutsa Member (J2) } \\
92,536(92,914 \pm 2350) \text { [MIS 5c] } \\
121,731(125,530 \pm 4202) \text { [MIS 5e] } \\
\text { Kazarma Member (N2) } \\
90,863 \text { (90,990 } \pm 2918) \text { [MIS 5c] }\end{array}$ & $\begin{array}{l}\text { Well-preserved moraines and } \\
\text { extensive limestone pavements. } \\
\text { Well-defined lateral and arcuate } \\
\text { moraines in mid-valley positions. } \\
\text { Lowest elevation: } c .1500 \mathrm{~m} \text { a.s.l. } \\
\text { Note: the Kazarma Member is } \\
\text { interpreted as a periglacial unit }\end{array}$ & $\begin{array}{l}\text { The oldest secondary carbonates correlate } \\
\text { with MIS 5e. One date from Woodward et al. } \\
\text { (2004) overlaps MIS 5e and MIS 6. Later } \\
\text { phases of calcite deposition date from the } \\
\text { interstadials of MIS 5c and 5a. The glacial } \\
\text { units are correlated with MIS } 6 \text { (later Saalian) }\end{array}$ & $\begin{array}{l}\text { Profile development } \\
\text { index of } 29.8 \text { to } 38.3\end{array}$ \\
\hline Skamnellian & 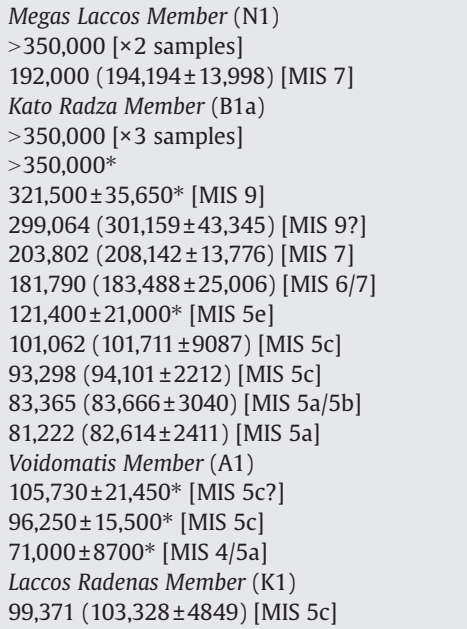 & $\begin{array}{l}\text { Extensive moraines that extend } \\
\text { down to the lower parts of upland } \\
\text { valley systems. These moraines are } \\
\text { more rounded in form than the } \\
\text { Vlasian moraines. The moraines } \\
\text { show thick and well-developed soils. } \\
\text { Lowest elevation: c. } 850 \mathrm{~m} \text { a.s.l. }\end{array}$ & $\begin{array}{l}\text { The oldest secondary carbonates are beyond } \\
\text { the range of U-series dating ( }>350,000 \text { years). } \\
\text { This stratigraphical unit also contains calcites } \\
\text { with ages correlating with MIS } 9,7,5 e, 5 \mathrm{c} \text { and } \\
5 \mathrm{a} \text {. The oldest secondary carbonates are } \\
\text { therefore correlated with MIS } 11 \text {. The glacial } \\
\text { units are correlated with MIS } 12 \text { (Elsterian) }\end{array}$ & $\begin{array}{l}\text { Profile development } \\
\text { index of } 51.8 \text { to } 61.0\end{array}$ \\
\hline
\end{tabular}

Dates marked with an asterisk are from Woodward et al. (2004).

ages > 350 ka (Table 1) (Woodward et al., 2004; Hughes et al., 2006a). The oldest secondary carbonates are therefore correlated with Marine Isotope Stage (MIS) 11 and the Skamnellian Stage glacial units are correlated with the Elsterian Stage of northern Europe and MIS 12 (Hughes et al., 2006a).

\subsection{The Vlasian Stage}

In broad terms, during the Vlasian glaciation, the maximum extent of ice cover extended over about one third of the area that was glaciated during the earlier Skamnellian glaciation with glacier ice covering an area of about $21 \mathrm{~km}^{2}$ on the slopes of Mount Tymphi. Significantly, much of the Astraka-Gamila plateau was ice free at this time while, further east, glaciers had advanced to mid-valley positions above Tsepelovo and Skamnelli (Fig. 4). During the maximum extent of this glaciation the mean ELA was c. $1862 \mathrm{~m}$ above sea level (Hughes et al., 2007). Eight uranium uranium-series ages have been obtained from secondary carbonates within this stratigraphical unit and the absence of secondary carbonates older than 131,250 $\pm 19,250$ years BP (Table 1) indicates that this phase of glacial activity took place before the last interglacial during MIS 6 (Hughes et al., 2006a). The Vlasian
Stage is correlated with the late Saalian Stage of northern Europe and MIS 6. It is quite likely that glaciers also developed during the cold stages between the Vlasian and Skamnellian Stages (i.e. during MIS 8 and MIS 10), but deposits from these periods have not been preserved. It appears likely that they were less extensive than the Vlasian Stage glaciers and were overrun and reworked by glaciers during this cold stage.

\subsection{The Tymphian Stage}

The final phase of glacial activity in the Voidomatis River basin took place during the last cold stage and this is known as the Tymphian Stage. The glacial deposits of this period are, as yet, undated because they do not contain secondary carbonates or organic materials (Table 1). The glacial deposits and landforms of this period are clearly younger than those of the Vlasian glaciation because they are found at much higher elevations and well within the limits of the Vlasian Stage deposits (Fig. 4). They also show only very limited evidence of pedogenic weathering (PDIs of 7.8 to 9.0) (Hughes et al., 2006a). The Tymphian Stage is correlated with the Weichselian/ Würmian Stage of northern Europe and the Alps, respectively, and MIS 
$5 \mathrm{~d}$ to 2 . The climate at the local glacier maximum during this stage would have been wet and cold. Rock glaciers also formed during this cold stage and provide evidence of cold and dry conditions after the local glacial maximum (Hughes et al., 2003, 2006a). The period of rock glacier formation probably correlates with the global LGM around 20 to $22 \mathrm{ka}$. About $15 \mathrm{~km}$ to the northeast of Mount Tymphi on Mount Smolikas (2637 m), well-developed moraines have been mapped at elevations above the floors of the highest cirques on Mount Tymphi (Hughes et al., 2006e). These glacial landforms post-date the youngest moraines on Mount Tymphi and it has been argued that they may be Younger Dryas in age - although this has not been confirmed by radiometric dating (Hughes et al., 2006e). Together these records show that, in the Pindus Mountains, climatic conditions were favourable for glacier development at various times during the last cold stage.

\section{Glacier dynamics and the Pleistocene fluvial system: meltwater routes and sediment fluxes}

The glacial geomorphological record shows major differences in the extent and volume of ice cover between the three glacial stages for which evidence is preserved in the basin (Fig. 4). These differences would have produced marked contrasts in the volumes of meltwater and sediment delivered to the fluvial system during these cold stages with the largest meltwater floods taking place during the Skamnellian and Vlasian stages, respectively. Significantly, key differences also occur in the geography of the major ice masses between cold stages, with ice covering large parts of Mount Tymphi - including much of the Astraka-Gamila plateau - during the Skamnellian Stage, but not during subsequent cold stages. In contrast, the Astraka-Gamila plateau was largely ice free during the Vlasian Stage when the main glaciers were located further to the east with source areas in the cirques above Tsepelovo and Skamnelli (Fig. 4).

The geomorphological record also shows much better preservation of glacial depositional landforms (such as lateral and terminal moraines) in the eastern sector of the uplands on the slopes around the villages of Tsepelovo and Skamnelli. This contrasts markedly with the geomorphology of the Astraka-Gamila plateau where large-scale removal of glacial sediments has taken place (Hughes et al., 2006a). A singular feature of the Astraka-Gamila plateau is the distinctive arrangement of linear features and moulded bedrock forms that converge on the upstream end of the Megas Laccos Canyon (Fig. 5). This striking terrain indicates that, during the Skamnellian Stage, this part of the uplands saw sustained fluxes of ice and meltwater into the Megas Laccos Canyon.

Two major routes for the discharge of Pleistocene glacial meltwater into the Voidomatis River can be identified and these are shown in Fig. 4. Meltwater route 1 (MR1) drains through the Megas Laccos Canyon from the Astraka-Gamila plateau directly into the main Vikos Gorge. This route would also have received meltwaters from the smaller ice masses to the south of the Astraka peak. Meltwater route 2 (MR2) is the Upper Voidomatis Valley where glaciers drained to the river channel to the south of Tsepelovo and Skamnelli (Fig. 4). The glacial record shows that both routes would have been important during the Skamnellian Stage (MIS 12), but MR2 would have been dominant during the later Vlasian and Tymphian stages. MR2 would have been the only outlet for melting glaciers on the south side of the Tymphi watershed during the last cold stage (Fig. 4). In marked contrast to the Megas Laccos Canyon (Fig. 6), the Upper Voidomatis drains through a much narrower and smaller-scale limestone ravine upstream of Kipi (Fig. 1) where, in places, the valley floor is confined by bedrock walls less than $10 \mathrm{~m}$ apart. Glacial meltwaters also fed into

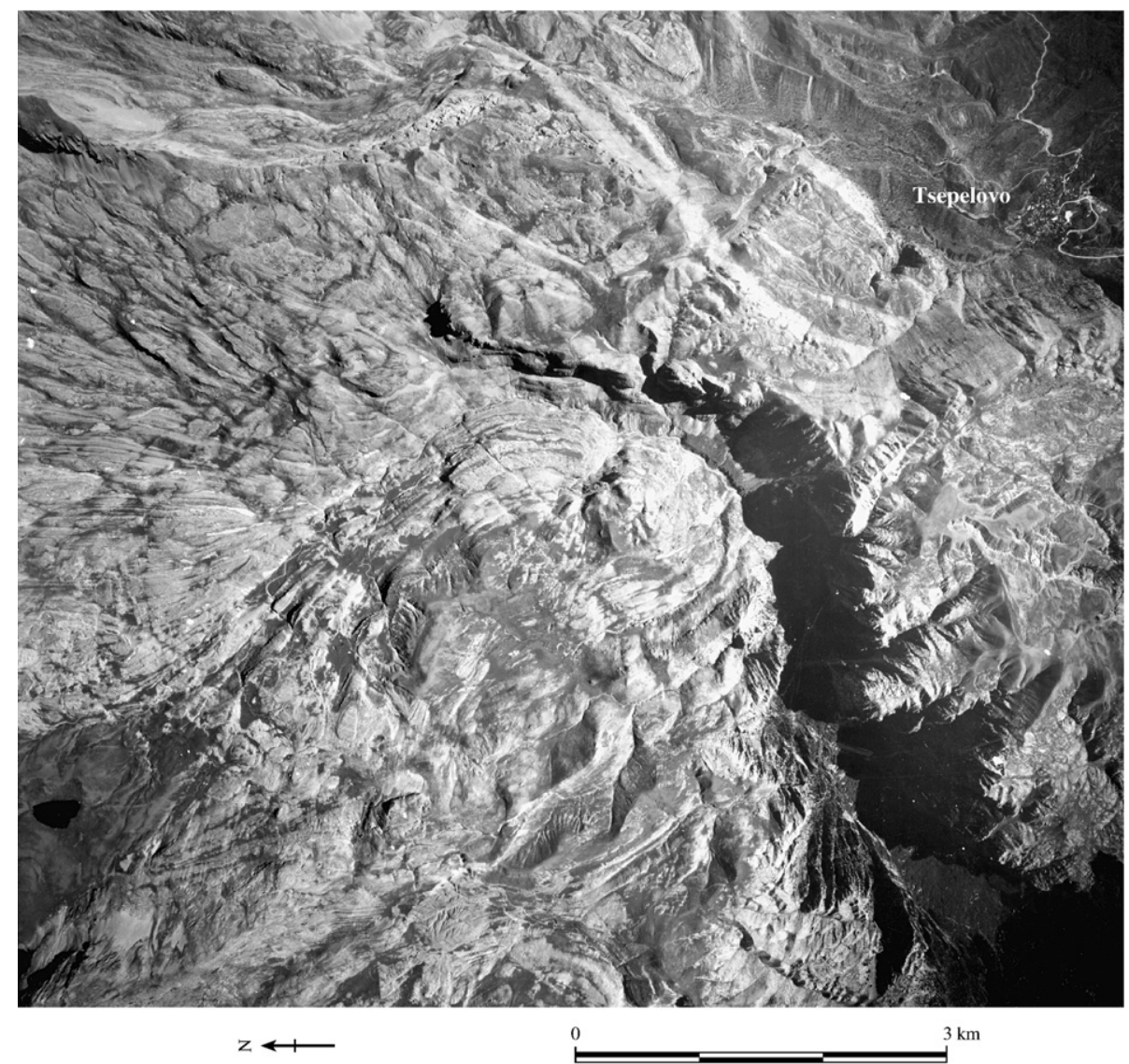

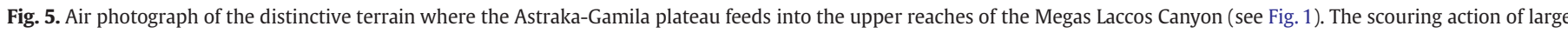

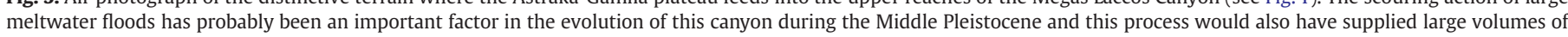
coarse sediment to the fluvial system downstream. 


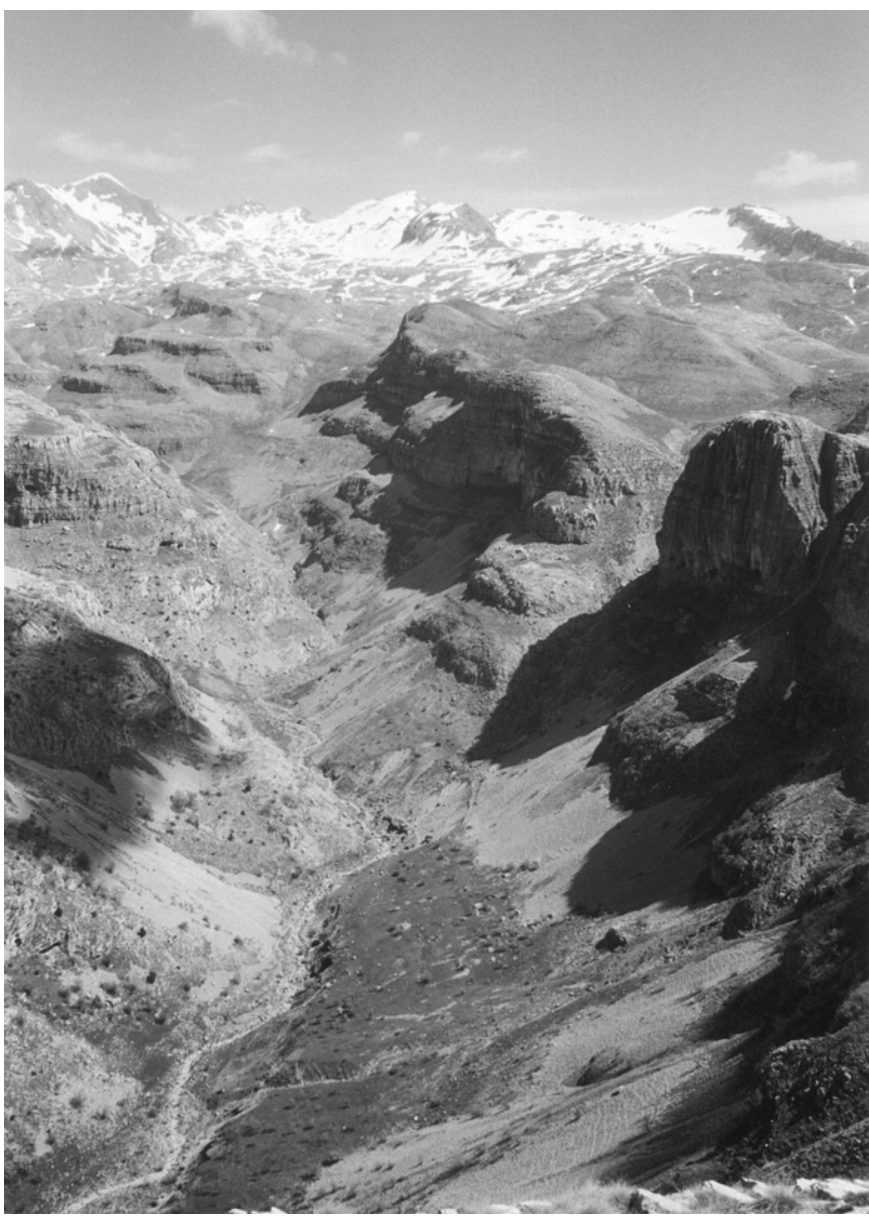

Fig. 6. View looking upstream into the Megas Laccos Canyon towards the high peaks and cirques of Mount Tymphi. Photograph by Philip Hughes.

the Aoos River catchment from the northern slopes of Mount Tymphi during the three main periods of glaciation (Fig. 4).

This implies that major sediment fluxes to the fluvial system took place from all parts of Mount Tymphi during MIS 12 - and the Megas Laccos Canyon was an especially important conduit for meltwater and sediment at this time. During MIS 6, however, the major flux of sediment from the glacial to the fluvial regime took place in the eastern sector of the catchment headwaters via MR2 in the Upper Voidomatis Valley when much of the Astraka-Gamila plateau was ice free (Fig. 4). During the Tymphian Stage (MIS $5 d$ to 2), when glacier ice covered a much smaller area $\left(<4 \mathrm{~km}^{2}\right)$ of Mount Tymphi, the magnitude of the meltwater and sediment fluxes was much reduced in comparison to the Skamnellian and Vlasian stages of the Middle Pleistocene.

In summary, the glacial record on Mount Tymphi shows that the dynamics of the cold stage river catchment changed quite dramatically during the course of the Middle and Late Pleistocene, with marked contrasts in the volume and extent of ice cover between cold stages as well as in the magnitude and routing of meltwaters and associated sediment fluxes to the fluvial system. This is analogous to the zonal coupling model of Harvey (2002) as the sediment supply conditions shifted between headwater areas during the course of the Middle and Late Pleistocene. During MIS 12, for example, very effective coupling and coarse sediment delivery may have occurred between the glaciers on the Astraka-Gamila plateau and the middle and lower reaches of the Voidomatis River via MR1 through the Megas Laccos Canyon (Fig. 4). In contrast, the very narrow gorge near Kipi along MR2 may have become periodically choked by coarse sediments producing much less efficient coupling with the lower reaches of the Voidomatis River.

\section{The Pleistocene fluvial record}

The record of Pleistocene river behaviour in the Voidomatis River basin is shown in Fig. 7a. This record is based on the data reported in Lewin et al. (1991) and a more recent uranium-series dating programme combined with field mapping in three key reaches (I to III) in the Lower Vikos Gorge and the southern part of the Konitsa basin which are shown in Fig. 1. This record is based on field survey and terrace height data, lithological analysis of the coarse and fine sediment fractions of Quaternary alluvium, the use of pedogenic weathering indices for alluvial soils, and the application of TL, ESR, ${ }^{14} \mathrm{C}$ and uranium-series dating (Lewin et al., 1991; Woodward et al., 1994; Macklin et al., 1997; Hamlin et al., 2000; Woodward et al., 2001). The uranium-series dates (Fig. 7a) provide minimum ages for the fluvial deposits because they derive from the analysis of secondary accumulations of carbonate that formed within the coarse sediment matrix. These ages form a stratigraphically consistent age model that is in good agreement with the original ESR and TL dates published by Lewin et al. (1991). The two TL dates were obtained from fine-grained sediments collected from weathered red-brown alluvial soils on terrace surfaces (Lewin et al., 1991; Woodward et al., 1994). The TL age of $28.2 \pm 7 \mathrm{ka}$ was obtained from fine sediments in a well-developed red-brown soil profile in the upper part of U6. The age of $28.2 \pm 7 \mathrm{ka}$ probably reflects the deposition of more recent aeolian silts and fine sands during the cold and dry conditions towards the end of the last cold stage that were incorporated into the soil profile by pedogenic processes (Woodward et al., 1994). The three ESR ages were obtained from the teeth of a red deer mandible that was found in situ in association with Upper Palaeolithic flints. These materials were recovered from a layer of silty sands towards the lower part of an exposure in Aristi-type gravels underlying slackwater deposits at the downstream end of the Boila rockshelter reach (Fig. 1).

It can be argued that the calcite cements formed soon after the deposition of the river sediments because the observed uraniumthorium isochrons are strongly correlated $\left(r^{2}>0.98\right)$ and this indicates that the cements probably formed during a short time period (Hamlin, 2000; Kelly et al., 2000). This argument is supported by the three ESR dates from the $U 4$ alluvium which are in good agreement with the uranium-series ages of $24 \pm 2$ and $25 \pm 2$ ka from the same phase of aggradation (Fig. 7a). The time lag between the deposition of the coarse sediments and when conditions become suitable for calcrete formation is mainly controlled by the rate of vertical channel incision in each reach (which influences local groundwater levels) and pedogenic processes within the gravel matrix. The limestone-derived fine-grained matrix of the Aristi-type sediments (U7 to U4) provides an abundant supply of calcium carbonate for dissolution and reprecipitation within the alluvial units. Typically, the secondary carbonates formed in a distinctive, laterally continuous layer $(>1 \mathrm{~m}$ in thickness) that is resistant to erosion and often protrudes from natural river-cut sections. The alluvial units (U8 to U3) shown in Fig. 7a are now discussed in turn.

\subsection{U8 alluvium}

U8 is the Kipi Unit described by Lewin et al. (1991). It has only been identified at one location in the basin close to Kokoris Bridge several kilometres upstream of the main Vikos Canyon (Fig. 1). A TL date from these sediments gave an age of $>150 \mathrm{ka}$ and this provides a minimum age for the deposition of these sediments (Lewin et al., 1991). This alluvial unit is lithologically distinctive because it contains a very high proportion (81.3\%) of non-limestone clasts with 44\% derived from ophiolite and $36.7 \%$ from flysch rock types (Fig. 7b). The low proportion of limestone clasts (18.7\%) suggests that the Kipi (U8) river system predates the first glacial activity on Mount Tymphi because all of the glacial deposits are dominated by limestone-derived materials. Moreover, ophiolite rocks account for only a very small part 

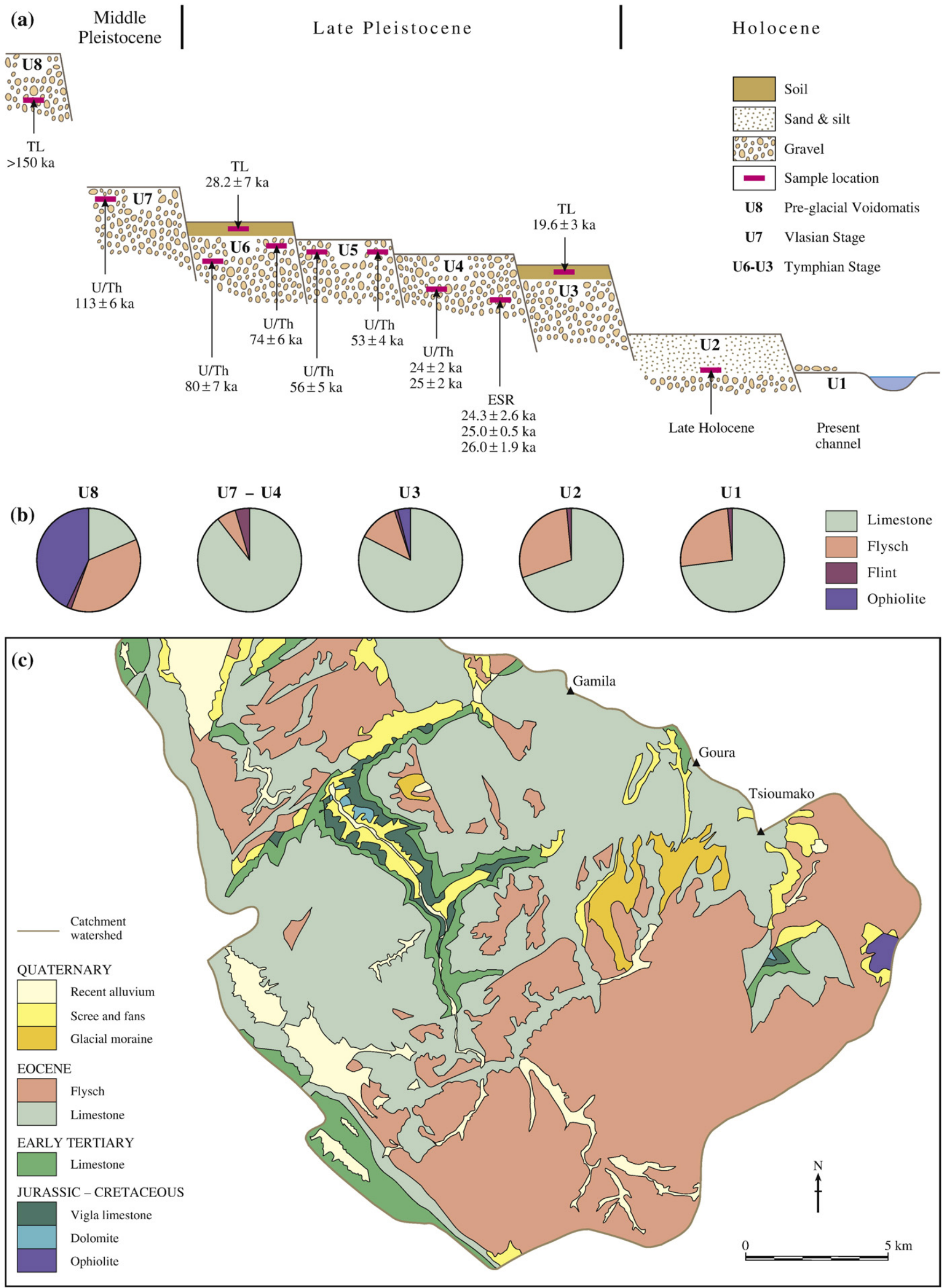
of the catchment (Fig. 7c) and the bed load of the modern river channel contains $<1 \%$ ophiolite. This alluvial unit must, therefore, record the activity of a fluvial system with a much more extensive catchment that drained areas to the east of the modern Voidomatis basin where extensive ophiolite terrains occur (Macklin et al., 1997). The U8 sediments must pre-date the Skamnellian glaciation of MIS 12 and are beyond the range of TL dating. This ancient pre-glacial river system is therefore not relevant to this discussion of glacial-fluvial linkages.

\subsection{U7 to U4 alluvium}

Lewin et al. (1991) described two Late Pleistocene alluvial units in the Voidomatis basin and named these the Aristi and Vikos units, respectively. The Aristi Unit is the most extensive Pleistocene alluvial unit with exposures recorded throughout much of the basin and an upper surface ranging in height from 6.7 to $25.9 \mathrm{~m}$ above the modern river bed. The coarse fraction of the Aristi Unit sediments is $>94 \%$ limestone (Fig. 7b) with a fine-grained sand- and silt-rich matrix dominated by limestone-derived material with a very similar mineralogy to the till matrix in the headwaters. Woodward et al. (1992) argued that the large quantity of limestone-derived silts, forming the matrix between the coarse clasts, could only be produced by crushing in a glacial environment. The Aristi Unit sediments comprise flat-bedded or massive, matrix-rich cobble gravels with occasional boulder-sized clasts that were deposited by an aggrading, low sinuosity river system with a high suspended sediment load (Lewin et al., 1991). One TL date and three ESR dates from exposures at the downstream end of the Lower Vikos Gorge ranged from $28.2 \pm 7$ to $24.3 \pm 2.6 \mathrm{ka}$ and indicate that the Aristi Unit sediments were deposited towards the end of the last cold stage (Lewin et al., 1991) (Fig. 7a). Later work, based on an investigation of pedogenic weathering on terrace surfaces, showed that the Aristi Unit could be subdivided into at least two distinct periods of Late Pleistocene alluvial sedimentation. Linear extrapolation of a pedogenic weathering index suggested that an earlier phase of Aristi-type aggradation (exposed in the Aristi to Papingo road reach, Fig. 1) took place sometime before $85 \mathrm{ka}$ (Woodward et al., 1994; Macklin et al., 1997).

Research in the lower basin in the late 1990s included detailed mapping of the southern Konitsa basin immediately downstream of the Lower Vikos Gorge (Figs. 1 and 8). This reach contains a more complete history of Pleistocene river behaviour and five Pleistocene river terraces, with mean elevations above the modern river channel of $15.5,12.75,11.0,10.0$ and $9.3 \mathrm{~m}$, respectively, have been recorded (Fig. 8b). Exposures in natural river river-cut sections allowed samples of secondary carbonates to be collected (Fig. 8b) and these have been dated using uranium-series methods. These data are shown in Fig. 7a. Exposures were not available in the sediments beneath the $11 \mathrm{~m}$ terrace and this intermediate surface between U6 and U5 has not been dated. It probably represents an incisional terrace surface that formed sometime after $74.6 \mathrm{ka}$ and before $56.5 \mathrm{ka}$ as the Voidomatis channel incised and migrated progressively westwards (Fig. 8b) (Hamlin et al., 2000). In combination with the existing TL and ESR dates of Lewin et al. (1991), the uraniumseries dating programme has allowed the Aristi-type sediments to be further sub-divided into four discrete alluvial units (Hamlin, 2000; Hamlin et al., 2000) and these are shown as U7 to U4 in Fig. 7a. Each one is dominated by limestone gravels with a small component of flint and flysch (Fig. 7b).

\subsection{U3 alluvium}

The Vikos Unit is shown as U3 in Fig. 7a. It represents a relatively minor phase of aggradation that is stratigraphically younger and much less extensive that the Aristi Unit (U7 to U4) sediments (Lewin et al., 1991). Significantly, its clast composition is intermediate between the Aristi Unit (U7 to U4) deposits and the Holocene and contemporary river gravels (U2 and $\mathrm{U} 1$ ). It comprises $82.3 \%$ limestone, $12.8 \%$ flysch and a significant (4.3\%) ophiolite component (Fig. 7b) that indicates that sediments from lower elevations in the Upper Voidomatis Valley and beyond the limits of Pleistocene glaciation - were important sources of sediment at this time (Fig. 7c). Lewin et al. (1991) argued that the Vikos Unit sediments represented deglacial conditions in the Voidomatis basin and a reduction in the supply of limestonederived materials from the glaciated terrains. The mineralogy of the fine matrix provides additional support for this assertion as it contains a dominant flysch component but with a minor contribution from the

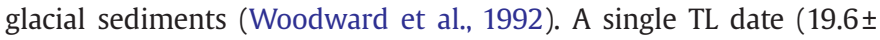
$3.0 \mathrm{ka}$ ) was obtained from this unit from a site immediately upstream of the Aristi to Papingo road reach (Fig. 1). This age overlaps with the slackwater sediments from Boila rockshelter and will be discussed further below.

In summary, five Pleistocene-age alluvial units (U7 to U3) have been identified and dated in the Voidomatis basin. The geochronology for the fluvial record has been compiled over several field campaigns using a combination of TL, ESR, uranium uranium-series and radiocarbon dating in conjunction with pedogenic weathering data (Lewin et al., 1991; Woodward et al., 1994; Macklin et al., 1997; Hamlin et al., 2000; Woodward et al., 2001). Good agreement exists between these independent dating methods and an internally consistent geochronology has been assembled for Late Pleistocene river dynamics. The Holocene alluvial record (U2 and U1) is not discussed in this paper.

\section{The Pleistocene glacial and fluvial records}

This section evaluates the glacial and fluvial records and proposes a model of long-term river response to headwater glaciation for the Voidomatis River basin that may have some broader significance for mountain catchments in the Mediterranean. In addition, this analysis provides the long-term geomorphological context for the slackwater sediment record that is discussed in the final part of this paper. The correlations between the glacial and fluvial records in the basin are shown in Fig. 7a and discussed in detail below.

\subsection{Middle Pleistocene river behaviour}

U7 is the oldest of the Aristi-type sedimentary units so far identified in the basin and it represents the thickest and most extensive body of sediment in the fluvial record. This unit is well exposed on the Konitsa basin immediately downstream of the Lower Vikos Gorge where it forms a prominent terrace about $15.5 \mathrm{~m}$ above the modern channel as shown on Survey Profile 1 (Fig. 8b). The valley floor is over $800 \mathrm{~m}$ wide at this point and solely on the basis of sediment volume, U7 represents a major increase in sediment supply from the upstream catchment. The younger Pleistocene alluvial units exposed in the Konitsa basin reach (U6 to U4) represent much smaller aggradations that formed within a narrower valley floor following 

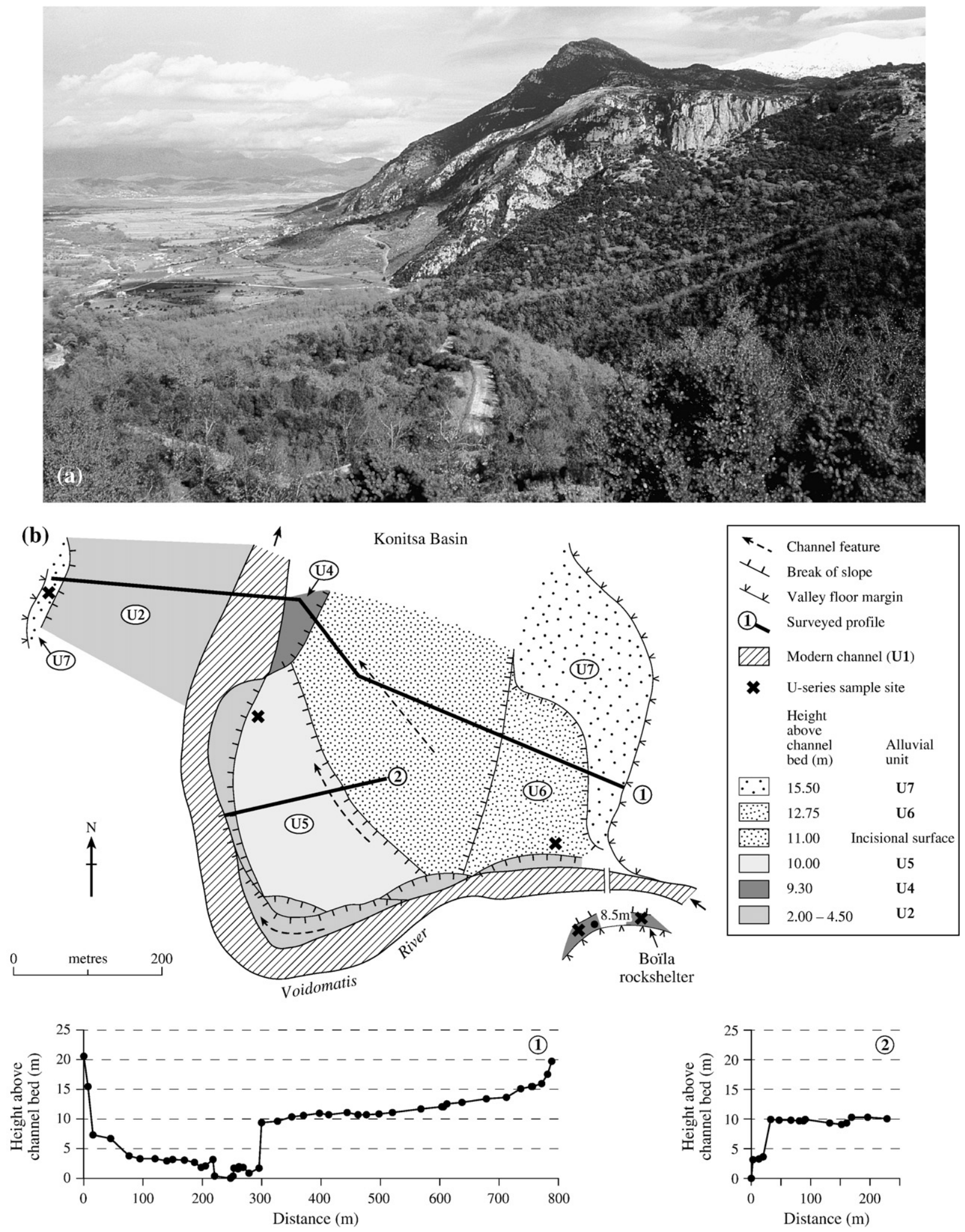

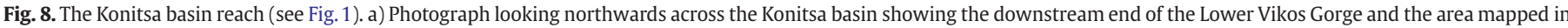

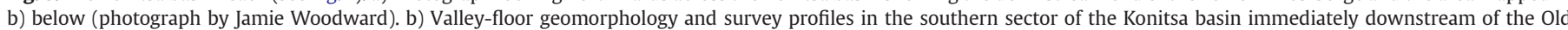
Klithonia Bridge (based on Hamlin, 2000; Hamlin et al., 2000). This part of the basin provides the most complete record of Middle and Late Pleistocene river behaviour.

down-cutting into the U7 alluvium (Fig. 8b). The U7 terrace can be traced several kilometres downstream towards the Aoos-Voidomatis confluence (Lewin et al., 1991). A single uranium uranium-series age of
$113 \pm 6$ ka was obtained from a sample of secondary carbonate collected from the upper $2 \mathrm{~m}$ of this alluvial unit on the western edge of the Konitsa basin (Fig. 8b) (Hamlin et al., 2000). This date 
places the calcrete formation towards the early part of MIS 5 close to the $5 d / 5 e$ boundary. This provides a minimum age for the upper part of the U7 alluvium. In view of the geomorphological context and the data now available for the glacial history of the catchment headwaters, it would, therefore, seem likely that the main period of U7 aggradation took place during the Vlasian Stage (MIS 6). This was the second most extensive glaciation in the basin when glaciers reached mid-valley positions on Mount Tymphi. As Macklin et al. (2002) have observed, major phases of fluvial aggradation have been identified elsewhere in the Mediterranean region during MIS 6, with well-dated evidence in northeast Spain (Fuller et al., 1998), Libya (Rowan et al., 2000) and in the Sorbas basin of southeast Spain (Kelly et al., 2000).

If fluvial sediments relating to earlier (pre-MIS 6) glaciations have been preserved, they are probably buried below the Vlasian Stage fluvial sediments on the Konitsa basin and can, therefore, only be identified from borehole records. Such deposits may also have been preserved in the river terrace record in Albania downstream of the Aoos-Voidomatis confluence. The geomorphological record on the Astraka-Gamila plateau indicates that a large volume of Skamnellianage glacial sediment has been removed via MR1 into the Vikos Gorge. High energy gorge environments do not, however, favour the longterm storage of large volumes of fluvial sediment and both Skamnellian- and Vlasian-age fluvial deposits appear not to have been well preserved in the major gorges in the basin. Fragments of Middle Pleistocene alluvium are difficult to identify with certainty because data on terrace heights do not allow a definitive separation in the narrow, steep-gradient gorges and it is not possible to differentiate between the U7 to U4 sediments on the basis of clast lithology (Fig. 7b). In addition, soil profiles than can be used to develop age models are not well preserved on all the terrace surfaces. As Lewin and Macklin (2003) have observed more generally for narrow and incised valley valley-floor settings, the development of new valley-floor units is necessarily at the expense of reprocessing earlier ones and in this case the Vlasian-age fluvial sediments in the main gorges have probably been subjected to extensive reworking by large floods during the Tymphian Stage.

An important question that is difficult to address is the amount of time needed to transport the inputs of fluvial sediment from the major Middle Pleistocene glaciations through the middle reaches (Vikos Gorge and Lower Vikos Gorge) of the catchment (Fig. 1). The inputs of coarse sediments to the fluvial system from Vlasian Stage glaciers via MR2 in the Upper Voidomatis Valley would have involved longer transport distances than those that were introduced via the Megas Laccos Canyon (MR2) during the Skamnellian Stage (Figs. 1 and 4). The limestone-dominated coarse alluvial sediments of the Late Pleistocene (U6 to U4) may represent, in part, a legacy of the enhanced sediment fluxes associated with the large Middle Pleistocene glaciations. The geomorphological record is rather anomalous in that the last cold stage produced relatively small glaciers on Mount Tymphi, but the fluvial record saw large-scale aggradations in the lower reaches of the catchment during this period (Figs. 7a and 8). One explanation is that this may, in part, be the legacy of the major volumes of fluvial sediment supplied to the gorge systems during MIS 6. Alluvial units U6 to U4 may have been deposited during large floods that reworked significant volumes of glacial material and coarse-grained river sediment that had been deposited in the major gorge systems downstream during the Middle Pleistocene glaciations.

\subsection{Late Pleistocene river behaviour}

If we assume that the U7 aggradation was deposited during the Vlasian Stage (MIS 6), then the pattern of coarse sediment reworking and downstream transfer observed in the Late Pleistocene alluvial record (U6 to U4) may be a good model for the earlier glacial-fluvial interactions of Stage 12 and the geomorphological legacy it left for subsequent cold stages. In other words, the Middle Pleistocene glaciations may have generated extended periods of paraglacial sedimentation (Church and Ryder, 1972). In comparison to the large Middle Pleistocene glaciations, coarse sediment delivery to the fluvial system via meltwater floods is likely to have been much reduced during the last cold stage because of the restricted size of the Tymphian glaciers (Fig. 4). The Late Pleistocene fluvial record, however, shows clearly that increases in sediment supply produced major aggradations (U6 to U4) in the lower reaches of the catchment (Fig. 7a) and the fine-grained, glacially-derived matrix within these sediments points to the importance of meltwater-generated floods from the Upper Voidomatis Valley via MR2 (Fig. 4) (Woodward et al., 1992). The Tymphian glaciers may well have advanced and retreated several times during the course of the last cold stage. Indeed, from an analysis of data on Mediterranean sea surface temperature and pollen-based reconstructions of precipitation from nearby Lake Ioannina (Fig. 1), Hughes et al. (2006d) have identified 10 periods that, theoretically, would have favoured glacier development in the Pindus Mountains between 110 and $10 \mathrm{ka}$. The fluvial system is clearly sensitive to change, even when the glaciers were restricted in size, but the long-term record of coarse sediment delivery to the lower reaches of the basin may partly reflect inheritance and recovery from large shifts in sediment inputs to the upper reaches that characterised the earlier cold stages. Indeed, the large proportion of limestone in the Holocene and modern river gravels (c. 69 to $73 \%$ ) may partly reflect the continued reworking of bed load materials that were first mobilised during the large Middle Pleistocene glaciations.

Large glaciers did not develop in northwest Greece during the last cold stage because the climate was never cold and wet for long enough - precipitation inputs were not sufficient to maintain a positive mass balance for extended periods (Hughes et al., 2006d). The cold and dry phases of climate in the Tymphian Stage that produced rock glaciers in the cirques on Mount Tymphi would also have enhanced periglacial weathering of the limestone canyon walls throughout the basin. While this may have been an important source of coarse sediment to scree slopes and valley sides, however, it is not possible to establish whether it would have been a significant contributor to the channel zone in comparison to the volume of sediment that could be generated by the reworking of existing glacial and fluvial sediments on the valley floor during large floods. This discussion of long-term catchment dynamics, sediment sources, and glacial-fluvial interactions provides important context for the slackwater sediment records in the Voidomatis basin.

\section{A Mediterranean-wide perspective}

Fig. 9 presents data from river basins across the Mediterranean and allows the record for the Voidomatis basin to be placed within a broader regional context. Over the last ten years or so, the wider application of a range of dating techniques has seen the number of river basins in the region with well-dated records of Late Pleistocene river behaviour increase significantly. Fig. 9 focuses on the period from $c .130$ to $10 \mathrm{ka}$ and shows that, in general terms, major phases of aggradation took place in many river basins during periods of cooler climate that saw increases in sediment supply from hillslopes to river channels (Fuller et al., 1998; Macklin et al., 2002). These were commonly followed by periods of channel incision during warmer and wetter phases when sediment supply decreased as forest cover expanded. The Voidomatis is the only catchment shown in Fig. 9 with widespread and unambiguous evidence for multiple Pleistocene glaciations, but major phases of alluviation took place at similar times across the Mediterranean region in river basins that were not glaciated. This was the result of more intensive weathering and more frequent large floods during periods of cooler climate that 


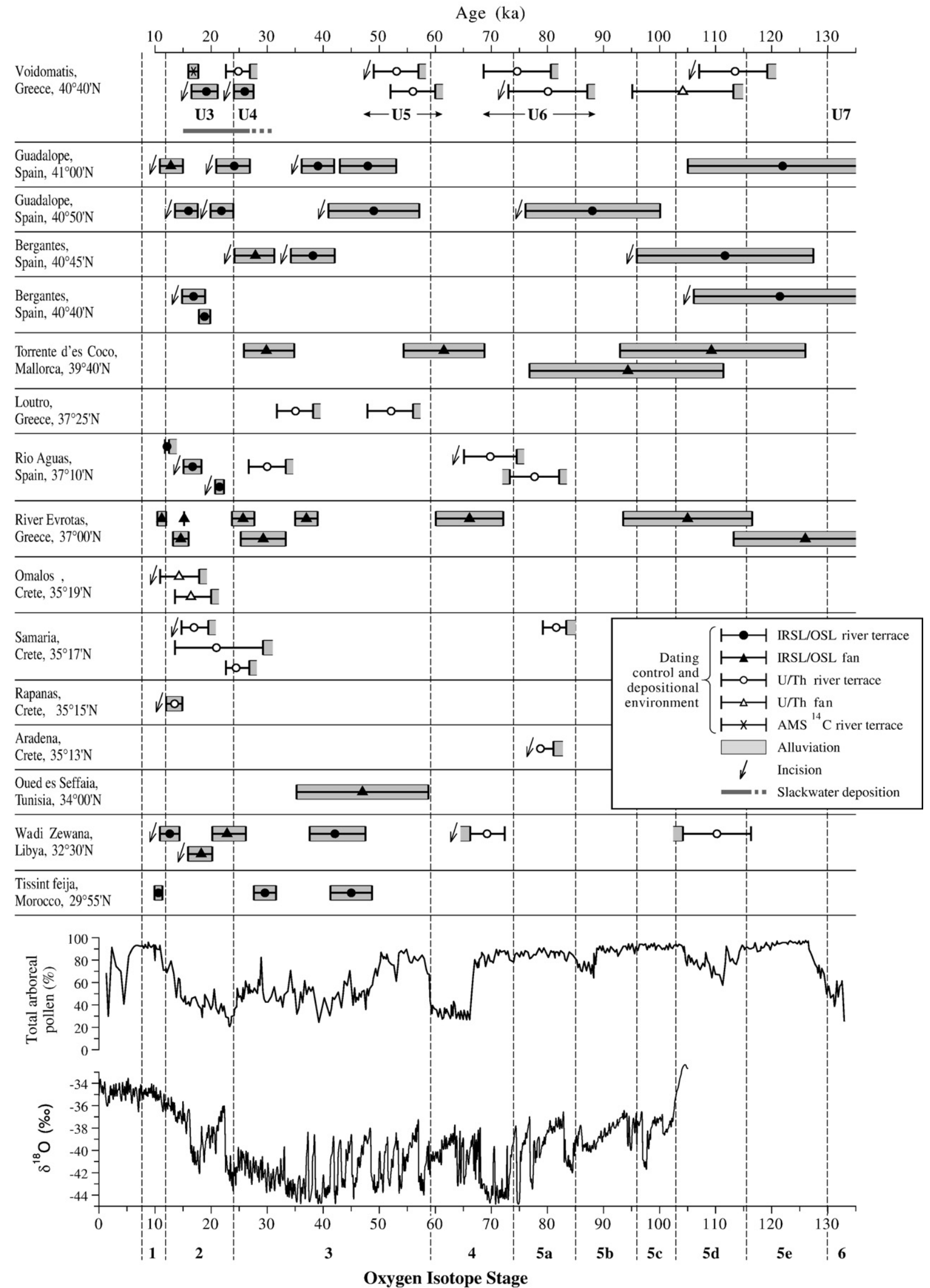


supplied large volumes of sediment to valley floors. The record shown in Fig. 9 no doubt partly reflects preservation factors and the error margins on the oldest deposits make correlations less robust, but an increasingly detailed record of Mediterranean catchment systems responding in a sensitive manner to Pleistocene climate change is emerging.

\section{Slackwater sediments in the Voidomatis basin}

Slackwater deposits were discovered at two sites in the Voidomatis basin in 1986 during the first phase of geomorphological field work (Lewin et al., 1991). A third site was identified in 1997 during the excavations at Boila rockshelter (Hamlin, 2000; Woodward et al., 2001). The following sections outline the geomorphological setting of each site to place the SWDs within the Quaternary fluvial stratigraphy shown in Fig. 7a.

\subsection{SWD site 1: The Tributary Site}

This site is located in a small left bank tributary near the Spiliotissa Monastery downstream of the Aristi to Papingo road bridge in the Lower Vikos Gorge (Figs. 1 and 10). The SWDs at this site were deposited within a narrow tributary in a classic backflooded tributary context (Baker et al., 1983; Kochel and Baker, 1988). The tributary stream has incised through coarse-grained alluvial sediments and the channel bed lies between 2 and $3 \mathrm{~m}$ below the terrace surface in the vicinity of the SWDs (Hamlin, 2000). A Pleistocene river terrace forms an important geomorphological feature on both sides of the valley floor in this part of the Lower Vikos Gorge (Fig. 10b). Coarse-grained Aristi-type sediments underlie this surface and they are clearly exposed in the road cut section on the eastern side of Survey Profile 7 (Fig. 10b) (Macklin et al., 1997). These deposits have not been radiometrically dated in this reach, but they have been tentatively correlated with the U6 alluvium on the Konitsa basin (Fig. 8b) (Hamlin, 2000) because the terrace lies at a similar elevation above the modern valley floor and a pedogenic weathering index developed for a thick alluvial soil exposed in the road cut section yielded a minimum age estimate of 85 ka (Woodward et al., 1994) that is in good agreement with the uranium-series ages shown in Fig. 7a. These sediments could be much older, however, and a correlation with the U7 alluvium on the Konitsa basin cannot be ruled out until more dates become available. The SWDs at this location clearly post-date the Pleistocene gravels.

The SWDs deposits are almost $3 \mathrm{~m}$ thick and comprise alternations of medium to fine sands and medium to coarse silts separated by sharp contacts. Sedimentary logs for two exposures at this site are shown in Fig. 11. Typically the SWDs are well sorted and devoid of structures - although some units display upward fining and occasional reverse grading. Fine laminations are also discernable in some units (Hamlin, 2000). A thin horizon of calcium carbonate cement was present in one of the recorded sections between 150 and $160 \mathrm{~cm}$ below the top of the exposure and this material yielded a uranium-series age of $21.25 \pm 2.5 \mathrm{ka}$ (Fig. 11). This date shows that at least part of this sequence was deposited during the Tymphian Stage during the global Last Glacial Maximum (Hamlin, 2000). At least part of this record is contemporaneous with the large flood events that produced the coarse-grained U4 alluvial sediments at Old Klithonia Bridge (Fig. 12) and on the Konitsa basin (Fig. 8). The modern tributary stream drains a steep catchment that includes the flysch terrain near the village of Aristi (Figs. 1 and 7c).

\subsection{SWD site 2: Old Klithonia Bridge}

The main body of SWDs at this site is located between $c .9$ and $11.5 \mathrm{~m}$ above the level of the modern river channel close to the old Klithonia Bridge. The local stratigraphic context for this site is shown in Figs. 8 and 12. These deposits form part of a longer sequence of limestone-rich U4 alluvial sediments that includes coarse-grained "Aristi-type" gravels and a distinctive bed of cemented gravels about $3 \mathrm{~m}$ in thickness. Calcium carbonate cements from this coarse-grained unit have yielded uranium-series ages of $24.0 \pm 2$ and $25.0 \pm 2 \mathrm{ka}$. These ages are in good agreement with the three ESR dates from fine-grained alluvial sediments beneath the cemented member (Lewin et al., 1991) (Figs. 7a and 13). These dates show that this body of alluvial sediment (including the main body of SWDs in its upper part) was deposited towards the end of the Tymphian cold stage. A detailed sedimentary log of the slackwater deposits at this site is shown in Fig. 13. As the SWDs at this site were deposited in a higher energy environment than the Tributary Site and Boila rockshelter, the sediments tend to be coarser with layers containing coarse sands and fine gravels intercalated with fine-grained alluvial units richer in silts and fine sands. It is likely that the SWDs at Old Klithonia Bridge are contemporaneous with at least part of the record at the Tributary Site and the implications of this will be explored further in the discussion of the sediment source data below.

\subsection{SWD site 3: Boila rockshelter}

Boila is a small north-facing rockshelter at the end of the Lower Vikos Gorge immediately upstream of the point where the river emerges onto the Konitsa basin (Figs. 2 and 12). The floor of the rockshelter lies about $11 \mathrm{~m}$ above the channel of the modern Voidomatis River as shown on Survey Profile 4 (Fig. 12b). The rockshelter opening is $17 \mathrm{~m}$ wide and the site has a floor area of about $80 \mathrm{~m}^{2}$ (Fig. 12a). Excavations at the site began in 1993 and have shown that the upper $80 \mathrm{~cm}$ of the deposit contains a rich Late Upper Palaeolithic (LUP) assemblage of faunal remains and lithics (Kotjabopoulou et al., 1997, 1999). The archaeological excavations have shown that the entire site, and all of the sediments that contain LUP materials, are underlain by well rounded, coarsegrained, limestone-rich Late Pleistocene (U4) alluvium (Fig. 14). The SWDs preserved at Boila lie between the archaeological horizons in the upper part of the stratigraphy and the U4 gravels below. The photograph in Fig. 14 shows a section in the rear of the excavation trench highlighting the marked contrast between the fine-grained SWDs and the overlying scree. The bulk of the LUP material has been found within the coarse angular scree sediments that were produced by frost shattering of the rockshelter wall. Some LUP materials were found within the uppermost SWDs and charcoal samples found in association with these materials have yielded radiocarbon ages of $13,810 \pm 200$ and $13,960 \pm 260$ radiocarbon years BP (Fig. 14). These artefacts represent the first sustained use of the site and they must have been discarded on the fine-grained alluvial surface.

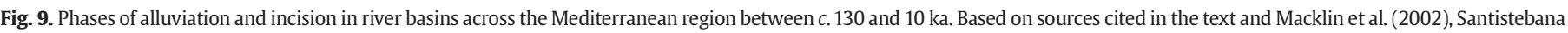

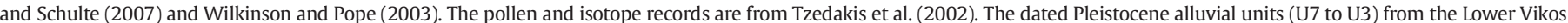

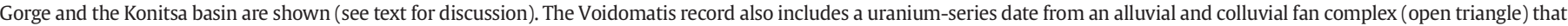

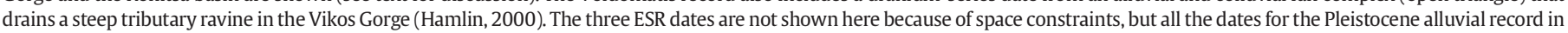

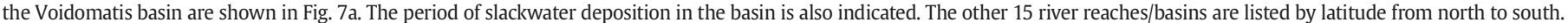



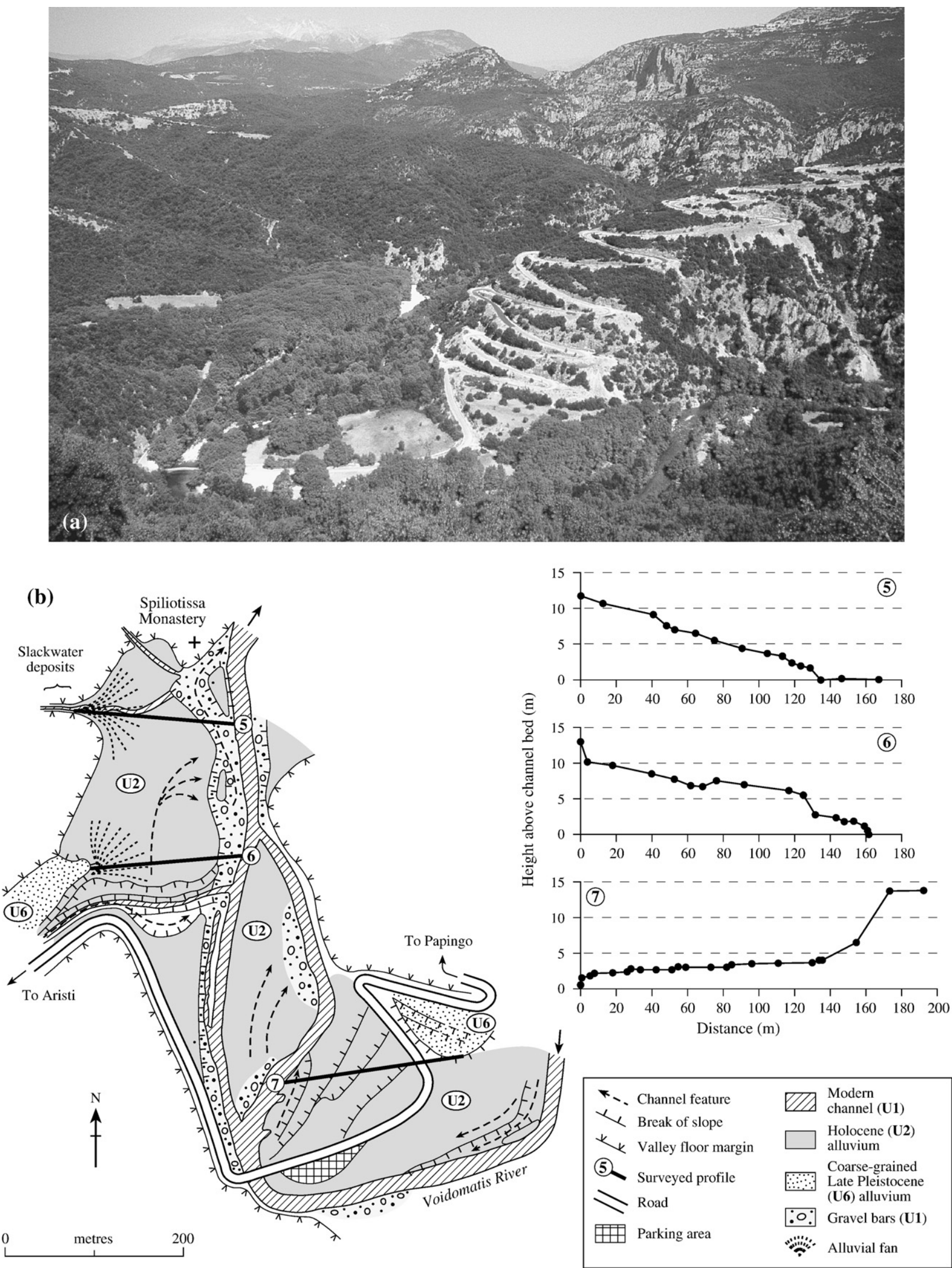

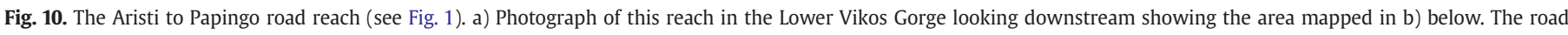

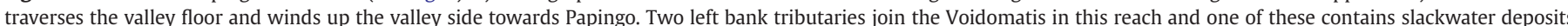

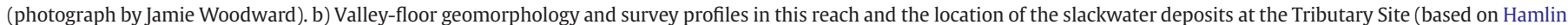

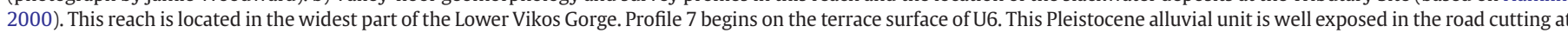

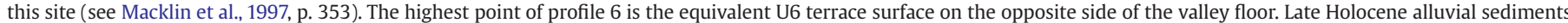
(U2) are well preserved in this reach on both sides of the modern channel complex. 


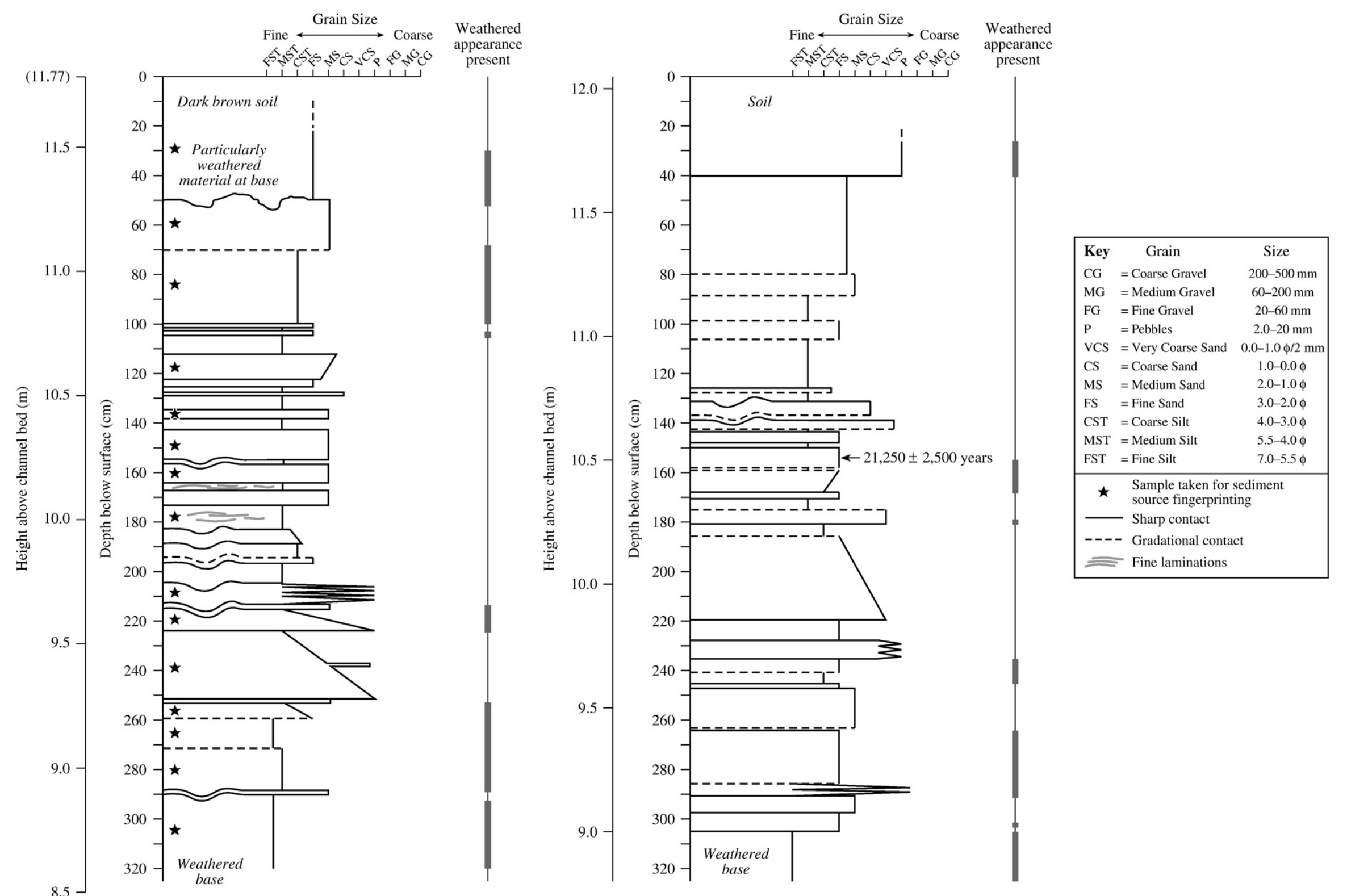

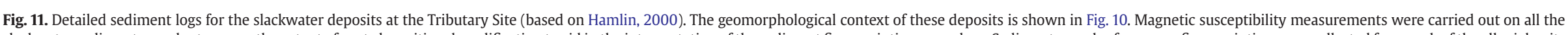

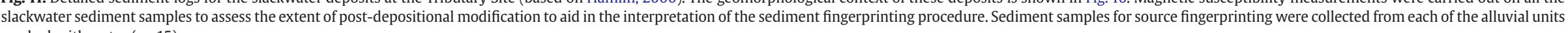
marked with a star $(n=15)$. 


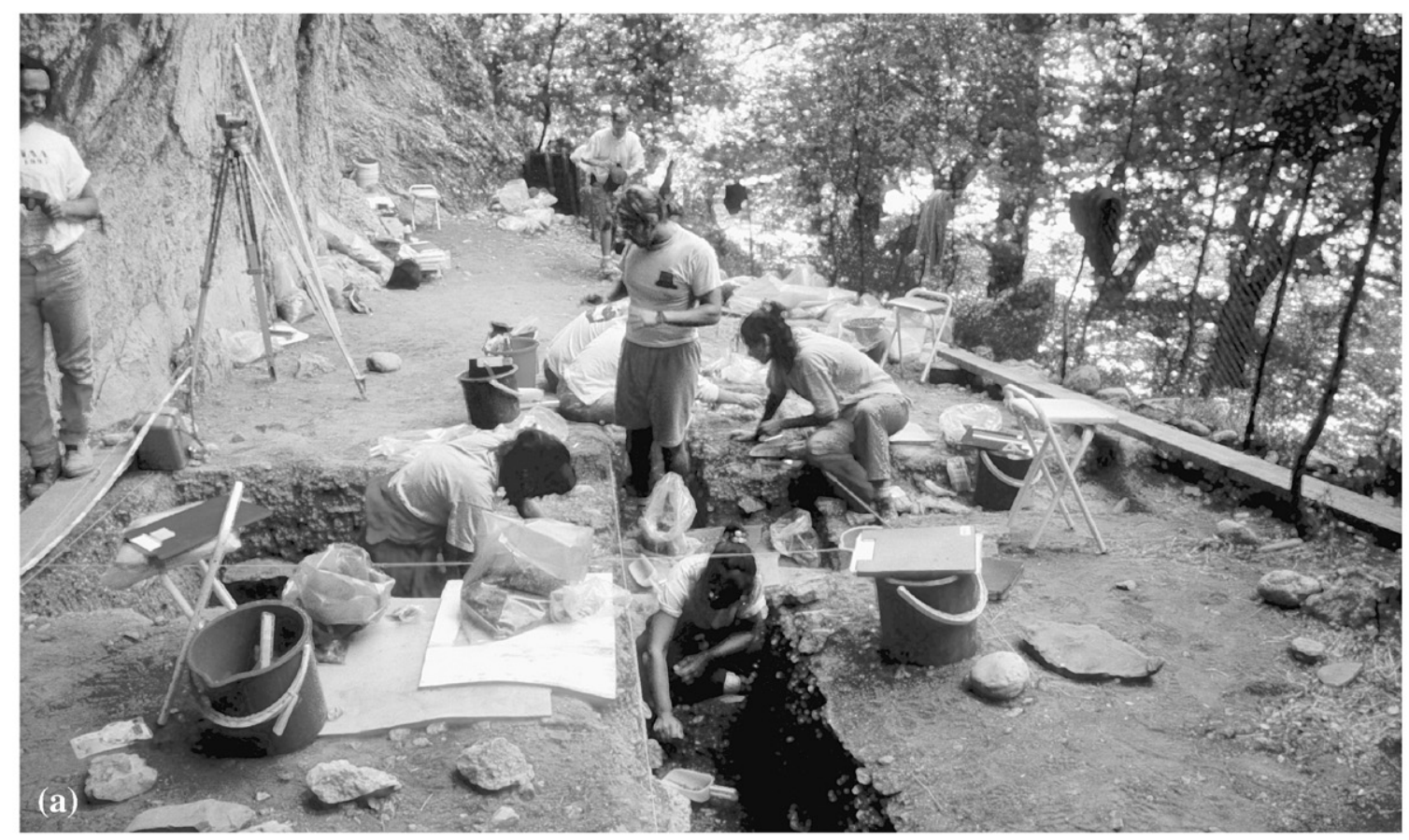

(b)

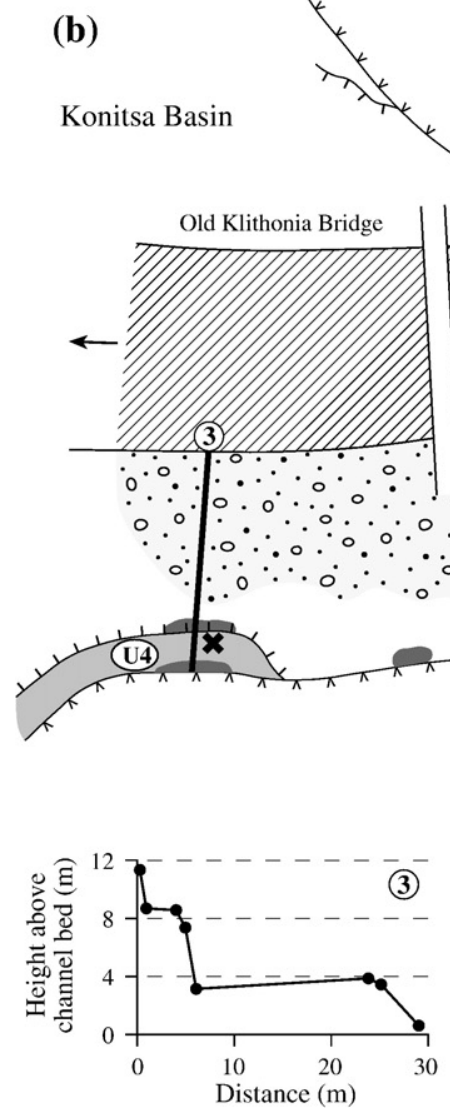

40
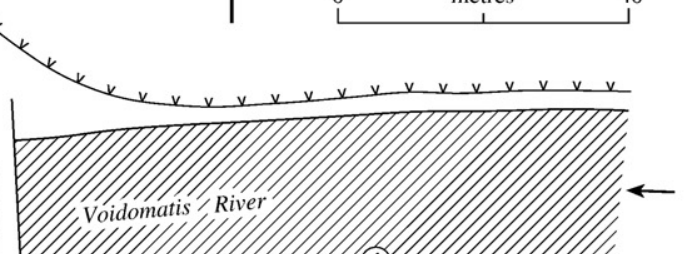

$4: \because \because 9 \because \div$

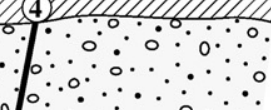

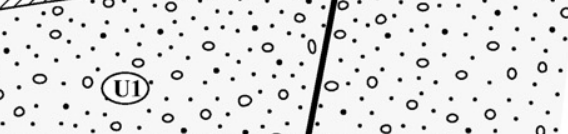

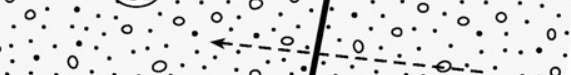

$\therefore 0$ Downstream end of

$\because \therefore \because 0 \%$ Lower Vikos Gorge

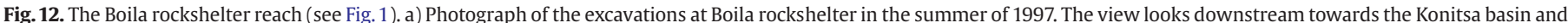

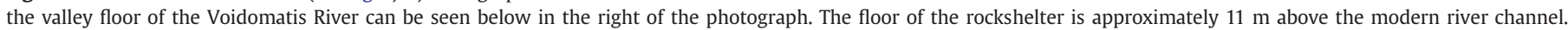

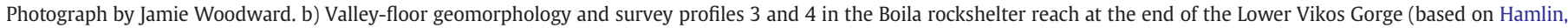
2000). The slackwater deposits at the Old Klithonia Bridge site are also shown.

The slackwater sediments were deposited before the LUP use of the site. The stratigraphy and archaeology of the site is discussed in detail in Kotjabopoulou et al. (1997, 1999) and Woodward et al. (2001). The main phase of slackwater deposition within Boila took place after about $14,310 \pm 200$ and ended around 13,960 \pm 260 radiocarbon years BP. Field observations and micromorphological work using large-format thin 


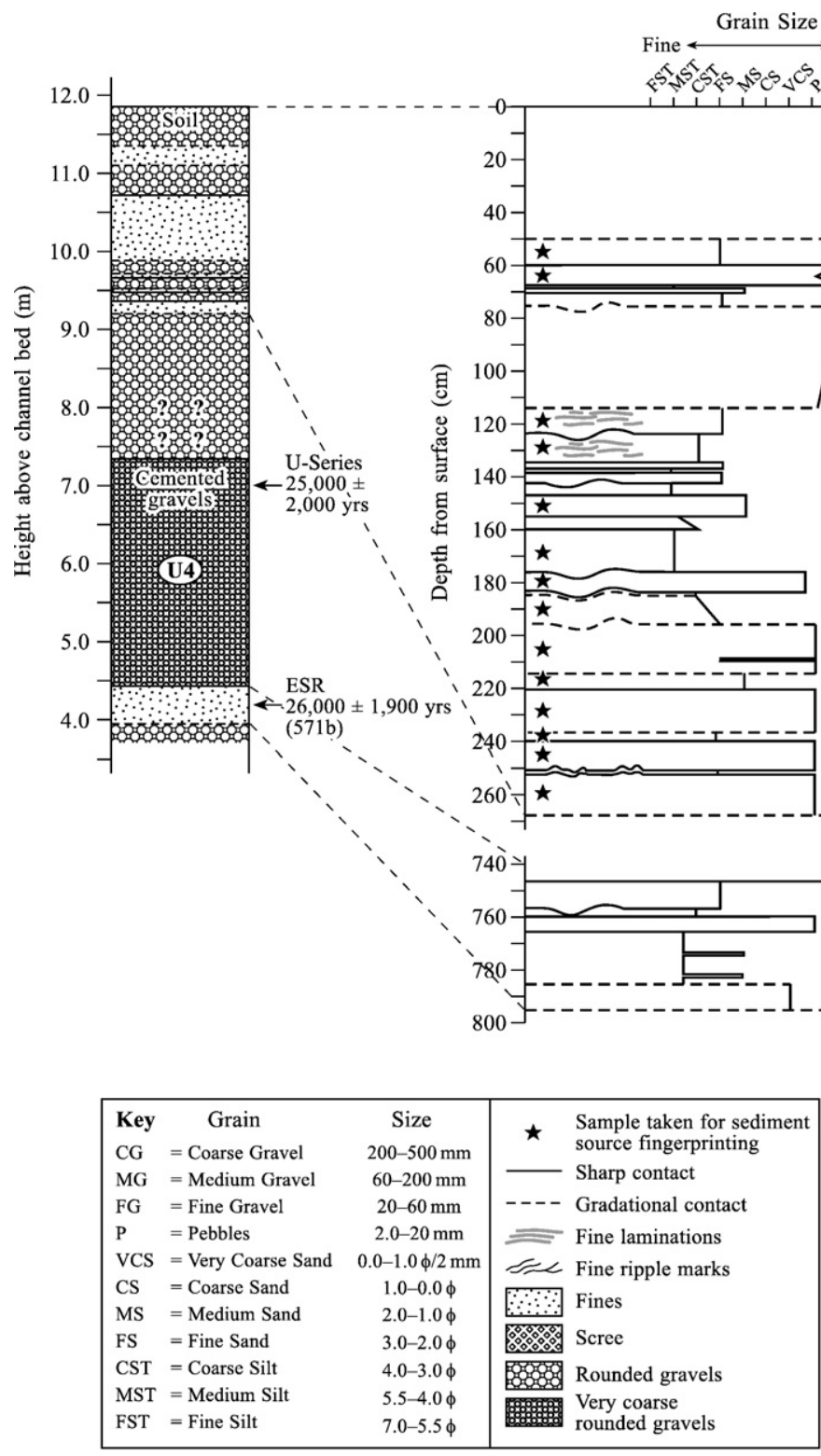

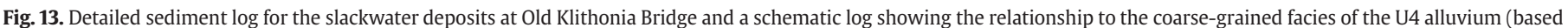

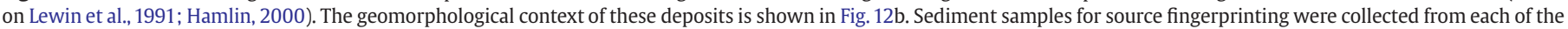
alluvial units marked with a $\operatorname{star}(n=14)$.

sections have shown that the coarse-grained angular sediments in the upper part of the record that contain the LUP assemblages do not contain any trace of alluvial sediments. This shows that floods were not large enough to inundate the rockshelter during or after the LUP use of the site (Woodward et al., 2001).

\section{Quantitative sediment sourcing of the slackwater deposits}

To investigate the dynamics of suspended sediment sources during the Tymphian Stage over the period of slackwater sediment deposition, a quantitative sediment fingerprinting approach was employed. This approach was originally developed to identify the source of recent estuarine deposits (Yu and Oldfield, 1989) and suspended sediment collected from contemporary floods (Walling and Woodward, 1995; Collins et al., 1997, 1998). It has also been successfully applied to Late Pleistocene (Hamlin et al., 2000; Woodward et al., 2001) and Holocene fluvial (Bottrill et al., 2000) and reservoir sediment records (Yu and
Oldfield, 1993). The full procedure for sediment sourcing used in the Voidomatis basin has been presented in detail by Hamlin et al. (2000) and Woodward et al. (2001) and is, therefore, only briefly outlined here. This approach has been successfully applied to the Boila slackwater sediment record and the provenance results have been tested qualitatively through the analysis of mineralogical data obtained from thin sections (Woodward et al., 2001). This final part of the paper presents the source data for all three slackwater sites so that catchment sediment supply dynamics can be observed throughout the course of the last glacial to interglacial transition.

Sediment samples $(n=38)$ were collected from all of the alluvial units within the SWDs marked with a star on the sedimentary logs shown in Figs. 11, 13 and 14. The sediments were then compared with the eight geological source materials shown in Table 2 following the methods detailed in Hamlin et al. (2000) and Woodward et al. (2001). A reference collection of source materials was assembled that included samples of all the main pre- 

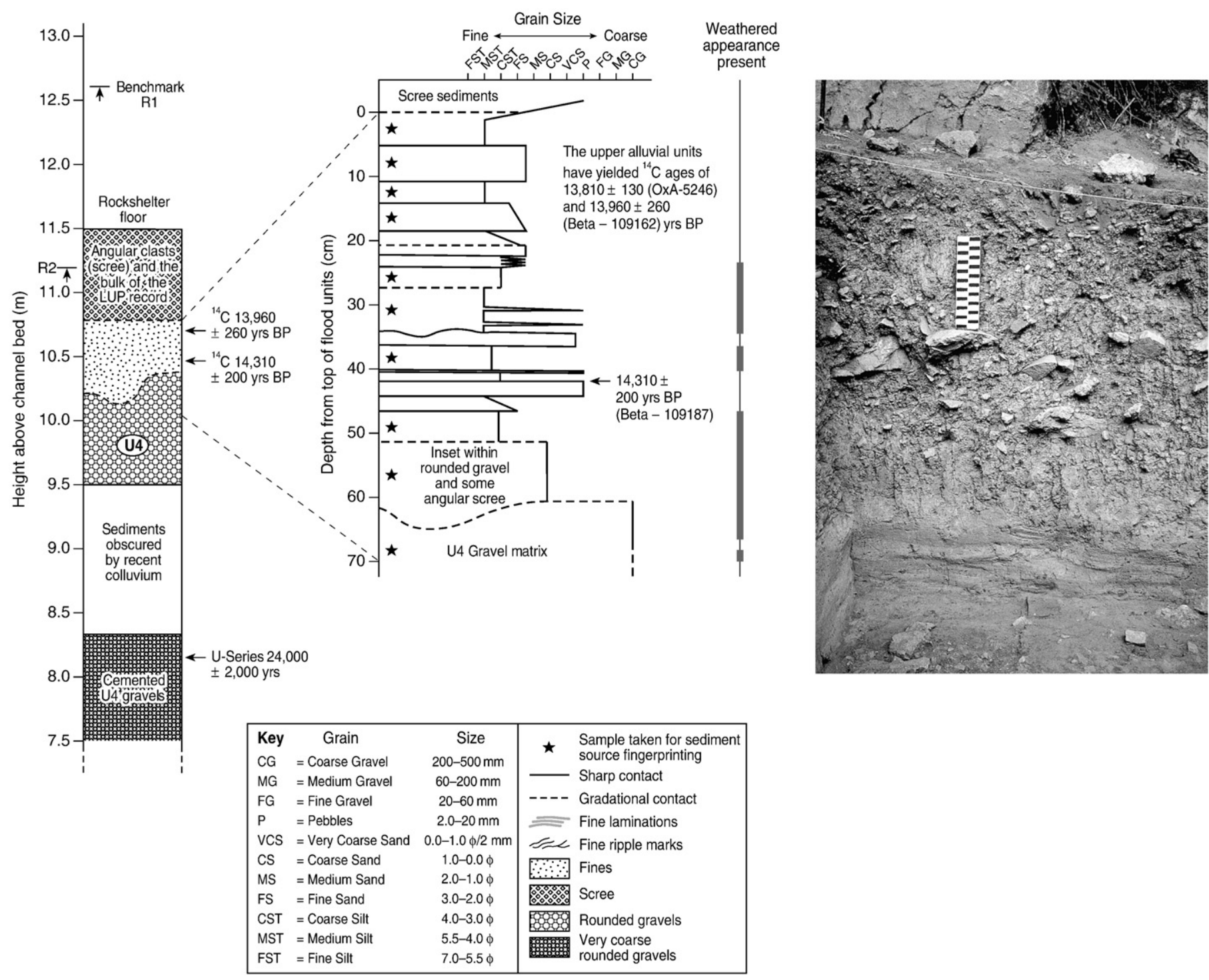

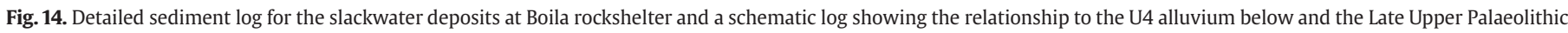

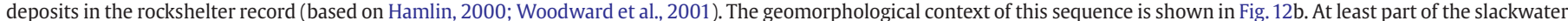

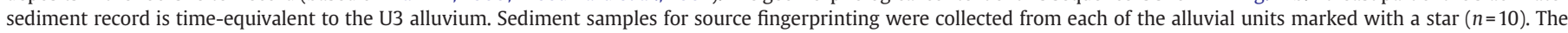

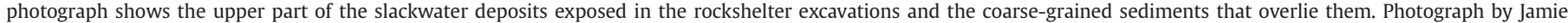
Woodward.

Quaternary rock types that outcrop within the drainage network (Fig. 7c) along with samples of fine-grained matrix from exposures in the glacial sediments and from terra rossa soils. In total, fifty two samples were collected from the eight potential source materials listed in Table 2. The aim of this approach is to identify a series of sediment properties or tracers that can be used to produce an objective estimate of the relative contribution of the potential sediment sources identified in the Voidomatis basin to the slackwater sediments preserved at the three sites. This involves four main stages and the following requirements must be met (Walling et al., 1993; Walling and Woodward, 1995; Collins et al., 1997; Hamlin et al., 2000; Woodward et al., 2001):

1) A series of tracer properties must be identified which are capable of discriminating between the potential catchment sediment sources shown in Table 2. The selected properties must be present in each of the source types so that a composite fingerprint can be identified for each source type. A combination of geochemical and mineral magnetic parameters was selected to meet this requirement. Major and minor trace elements ( $\mathrm{Ba}, \mathrm{Cu}, \mathrm{Cr}, \mathrm{La}, \mathrm{Nd}, \mathrm{Ni}, \mathrm{Pb}, \mathrm{Rb}, \mathrm{Sr}, \mathrm{V}, \mathrm{Y}, \mathrm{Zn}$ and $\mathrm{Zr}$ ) determined by XRF and low frequency and frequency dependent magnetic susceptibility were measured on all samples.

2) Next the selected combination of sediment properties must satisfy appropriate statistical tests of significance to establish that each of the sediment sources is clearly distinguished by its composite

Table 2

Sediment sources in the Voidomatis basin and the number of samples from each source used in the fingerprinting analysis

\begin{tabular}{ll}
\hline Source group & Samples $(n)$ \\
\hline 1. Limestone bedrock & 13 \\
2. Pleistocene till & 04 \\
3. Flysch bedrock & 18 \\
4. Dolomite-enriched flysch bedrock & 02 \\
5. Dolomite bedrock & 01 \\
6. Ophiolite bedrock & 03 \\
7. Pleistocene terra rossa (soil) & 04 \\
8. Reworked Late Pleistocene alluvium & 07 \\
\hline
\end{tabular}


Table 3

Selection of the tracers for the composite fingerprint based on multivariate discriminant analysis

\begin{tabular}{llc}
\hline Tracer & Wilk's lambda & \% correctly classified \\
\hline $\mathrm{Cr}$ & 0.00789 & 75.00 \\
$\mathrm{X}$ & 0.0000809 & 75.00 \\
$\mathrm{Zr}$ & 0.00000449 & 98.08 \\
$\mathrm{Ba}$ & 0.000000418 & 100.00 \\
$\mathrm{Sr}$ & 0.000000106 & 100.00 \\
$\mathrm{Y}$ & 0.0000000679 & 100.00 \\
$\mathrm{Rb}$ & 0.0000000312 & 100.00 \\
$\mathrm{Cu}$ & 0.0000000141 & 100.00 \\
$\mathrm{~V}$ & 0.00000000963 & 100.00 \\
\hline
\end{tabular}

Note that use of just the first four parameters results in all of the eight source groups shown in Table 2 being correctly classified.

fingerprint as shown by Walling and Woodward (1995), Collins et al. (1997) and Woodward et al. (2001). Kruskal-Wallis $H$-tests were applied to identify those parameters which were capable of distinguishing between the source groups. The tracer properties were also evaluated for reproducibility and long-term stability. The tracer parameters that passed these stages were then subjected to a multivariate discriminant analysis to identify those parameters whose combined signatures were best able to characterize, and differentiate between, the eight source groups (Hamlin et al., 2000; Woodward et al., 2001). Stepwise selection is achieved through the minimization of Wilk's lambda and the following parameters were used to form the composite fingerprint for the catchment source materials: $\mathrm{Ba}, \mathrm{Cr}, \mathrm{Cu}, \mathrm{Rb}, \mathrm{Sr}, \mathrm{V}, \mathrm{Y}, \mathrm{Zr}$ and magnetic susceptibility (Table 3).

3) An objective algorithm is then used which compares the composite fingerprint of each slackwater sediment sample with those of all potential sources and generates an estimate (\%) of the likely relative contributions of those sources to that sample (Yu and Oldfield, 1989; Walling et al., 1993; Walling and Woodward, 1995). A similar mixing model approach to that employed by Walling et al. (1993) has been used in the analysis of the slackwater sediment records.

4) Finally, where this is feasible, the results of the quantitative fingerprinting approach should be tested using independent data such as semi-quantitative assessment of the lithological composition of the sediments using data from thin sections (e.g. Woodward et al., 2001).

\section{Suspended sediment source dynamics during the Tymphian Stage: the last glacial to interglacial transition in the Pindus Mountains}

It is clear from the alluvial stratigraphy and its radiometric dating framework that the slackwater sediments at each of the three sites in the Voidomatis basin are Late Pleistocene in age and were deposited towards the end of the Tymphian Stage. The quantitative data on sediment sources from the three SWD sites are shown in Fig. 15. It is instructive firstly to discuss the results for the Old Klithonia Bridge and Boila rockshelter records because both sites are located at the end of the Lower Vikos Gorge close to the main channel and contain provenance signals that integrate processes operating in all of the upstream catchment. The slackwater sediments at the Old Klithonia Bridge section are older than the Boila SWDs, but stratigraphically younger than the strongly-cemented horizon that has yielded uranium-series ages of 24 and 25 ka (Figs. 13 and 14). These SWDs represent a series of floods that took place sometime after 24 ka but before 17.5 to $16.8 \mathrm{cal} \mathrm{ka}$ (the oldest radiocarbon date in the Boila slackwater sequence) - a period that straddles the global Last Glacial Maximum. These SWDs are dominated by limestone-derived materials and they contain a strong till signal throughout (Fig. 15). They were deposited by a series of large floods in a cold stage river system fed by meltwaters from glaciers on Mount Tymphi. The Tymphian glacial deposits have not been dated directly but the sediment source data indicate that glaciers were present in the limestone uplands at this time.

The Old Klithonia Bridge record contrasts markedly with the sediment source data for the younger SWDs at Boila because the latter record is dominated by flysch-derived fines. The Boila SWDs also contain a small but significant ophiolite component that points to the importance of sediment generation in the non-glaciated flysch terrains in the catchment headwaters upstream of Kokoris Bridge (Figs. 1 and 7c). The Boila slackwater sediments represent a series of rainfall-generated floods that took place after the final phase of Tymphian Stage glacial activity. Furthermore, the Boila source data indicate that reworking of existing glacial and cold stage alluvial deposits was not significant at this time because the sediments are dominated by flysch-derived materials. Flood units B1 to B4 all contain $>80 \%$ flysch and limestone-derived materials are absent from most samples. These data provide support for the argument that the strong glacial signal in the older SWDs in the Old Klithonia Bridge record represents the direct input of suspended sediments from Tymphian Stage glacial meltwaters. An increase in the limestone component is evident at the top of the Boila record (most notable in Flood Unit B5), but thin sections show that these are not fluvial sediments. They are angular limestone sand grains derived from frost weathering of the rockshelter walls and ceiling (Woodward et al., 2001). Sediments in rockshelters and caves may reflect a wide range of processes (Woodward and Goldberg, 2001) and this example highlights the importance of cross-checking the sediment provenance data with an independent method. Ophiolite fragments have also been identified in the same thin sections and this reinforces the reliability of the source data and highlights the importance of the lower elevation headwater catchments (upstream of Kipi) as a sediment source during ice-free periods.

During periods of warmer climate when glaciers are absent, surface runoff from the limestone uplands is limited because of the dominance of sub-surface drainage within the extensive glacio-karst system (see Waltham, 1978). At these times, suspended sediment in the main channel is mainly derived from the flysch terrains in the catchment. The fine fraction $(<63 \mu \mathrm{m})$ of the suspended load of the modern Voidomatis River is dominated by flysch-derived minerals (Woodward et al., 1992; Hamlin et al., 2000) and this appears to have been the case since the onset of slackwater sedimentation at Boila in the Late glacial. The source data for the Tributary Site (which drains a small flysch sub-catchment) show that flysch rocks did supply fine sediment to the fluvial system during cold stages (Fig. 15). It is also clear from the Late Tymphian SWDs at Old Klithonia Bridge, however, that this flysch-derived contribution to the trunk stream's sediment load was small (typically $<10 \%$ ) in comparison to the dominant contribution from glacial meltwater floods (Fig. 15).

Another feature of the catchment that must be considered is the role of the karst hydrological network. During the large Middle Pleistocene glaciations, surface runoff from glacial meltwaters would have fed directly into the river channel network because much of the upland limestone terrain was covered in ice, many conduits in the karst would have been choked with sediment or permanently frozen, and the glacier snouts were close to the modern valley bottoms. In contrast, during interglacial and interstadial periods, more effective coupling occurred between the surface drainage network and the internal karst drainage system. In Mediterranean limestone catchments with very high relief ( $>2000 \mathrm{~m}$ ), this vertical and horizontal coupling may represent an additional and important contrast between cold stage and warm stage hydrological dynamics (see Jakucs, 1977; Lewin and Woodward, in press).

While the Tymphian glaciers were small in comparison to those that formed during the Middle Pleistocene glaciations, the lithology of the slackwater sediments shows that they were still large enough to produce meltwater floods with suspended sediment loads dominated 

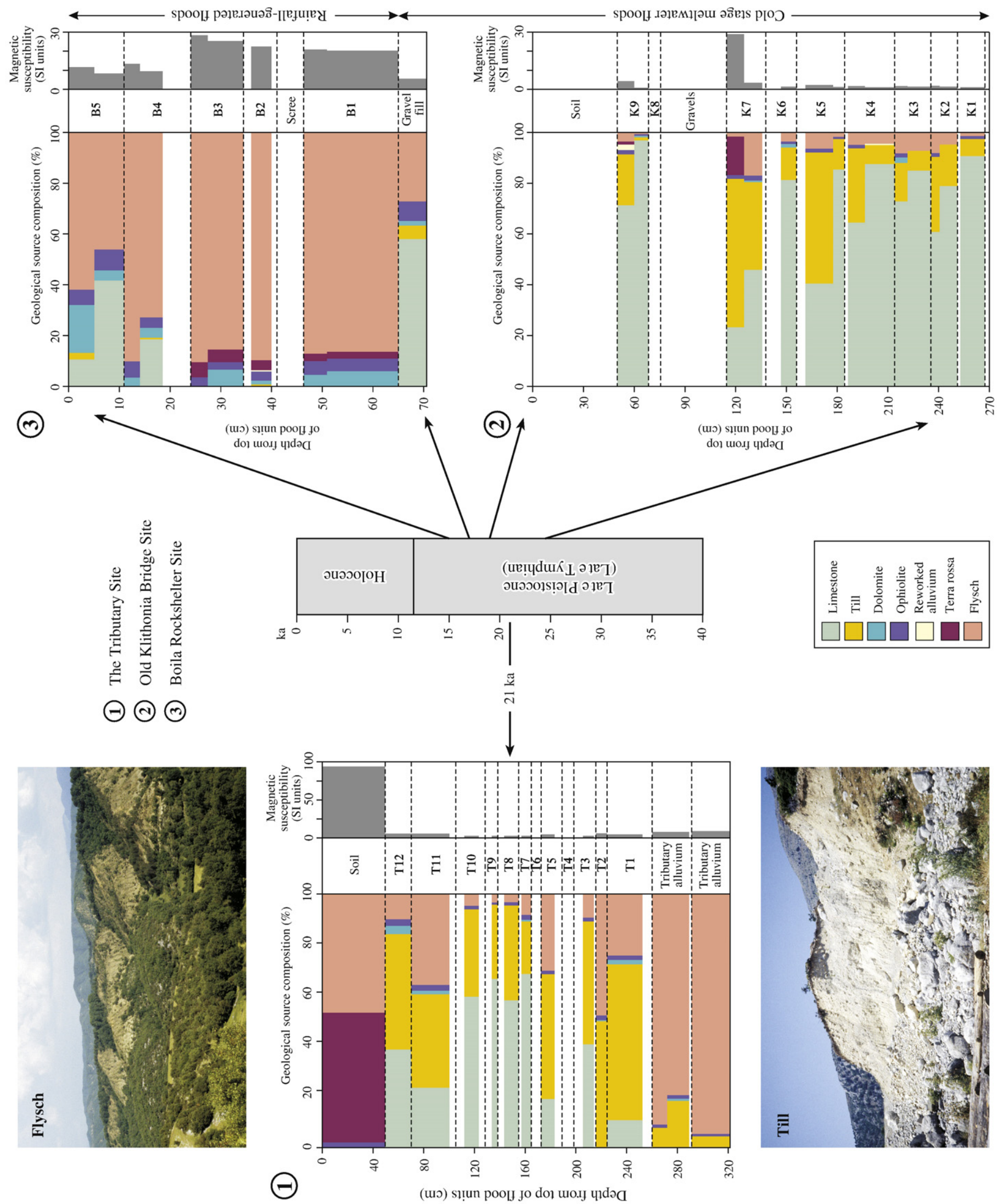
by limestone-rich till-derived sediments. Also, small glaciers may well have been present in the catchment during the periods when the U6 and U5 fluvial aggradations took place (Fig. 7a). The Tymphian stage meltwaters would have drained via MR2 to the Upper Voidomatis Valley and may have also entrained existing glacial sediments from the great thicknesses of Skamnellian and Vlasian deposits which mantled the slopes beneath them (Fig. 4). One possible explanation for the absence of a till signal in the suspended sediment load of the Late glacial and Holocene river is that such reworking does not happen once the glaciers have disappeared because much of the rainfall- and snowmelt-generated runoff on limestone terrains is lost to the karst system via the many dolines, sink holes and extensive bedrock pavements in the glaciated uplands (Fig. 3) (see Waltham, 1978). Furthermore, high resolution pollen data from Lake Ioannina have shown that refugial tree populations in northwest Greece expanded very rapidly following climatic amelioration (Tzedakis et al., 2002; Lawson et al., 2004). This would have radically altered catchment hydrology by reducing surface runoff and sediment availability. It is quite likely that the glacial deposits on the lower slopes around Tsepelovo and Skamnelli would have been stabilised by tree cover early in the Late glacial and throughout the period when the flood sediments were deposited at Boila rockshelter.

\section{Conclusions}

Recent research on the glacial and fluvial archives in the Voidomatis River basin has provided new insights into Pleistocene landscape dynamics in Mediterranean mountain catchments. The Voidomatis basin contains evidence for three major phases of glaciation with the two largest taking place during the Middle Pleistocene within MIS 12 and MIS 6. Glacial activity during the Middle and Late Pleistocene shifted the boundary conditions for fluvial activity in the Voidomatis catchment as the location and volume of glacier ice changed markedly between cold stages. This shifted the main routes for meltwater runoff and sediment delivery. The Vlasian Stage glaciation (MIS 6) is correlated with a major phase of fluvial sedimentation (U7 alluvium) preserved in the lower reaches of the catchment. Thus, the U7 sediments represent the oldest cold stage fluvial sediments so far identified that can be related to a period of glaciation. During the last cold stage (MIS $5 d$ to 2), the glaciers on Mount Tymphi were much smaller than their Middle Pleistocene counterparts, but they still exerted a major influence on sediment delivery and river behaviour. The Late Pleistocene contains the most detailed record of river behaviour with a series of coarse-grained terraced alluvial units produced by meltwater floods dating to this period. The basin preserves evidence of three phases of Late Pleistocene (Tymphian Stage) fluvial aggradation (U6 to U4) that are lithologically very similar to the glacial deposits in the catchment headwaters. Much of the coarse bed load sediment transported during the Late Pleistocene may have been inherited from the large sediment fluxes associated with the Middle Pleistocene glaciations.

The Voidomatis basin also contains fine-grained slackwater sediments that record the transition from the last glacial to interglacial conditions in the Mediterranean region and these have allowed a detailed examination of suspended sediment source dynamics during this period. The long-term model of catchment dynamics - based on the glacial geomorphology and the coarsegrained alluvial sediments - provides valuable context for an investigation of the Late Pleistocene slackwater sediment record. This record shows that glaciated Mediterranean catchments saw major changes in flood generation mechanisms, sediment fluxes and sediment sources during the last glacial to interglacial transition. This geomorphological response may be representative of earlier periods of change in the Middle and Late Pleistocene but the last (Late Tymphian) transition may have been more abrupt than earlier terminations because of the small size of the Tymphian glaciers.

The coarse-grained alluvial units have been dated using a range of methods and they provide a valuable, if fragmentary, long-term record of environmental change and incremental bed load flux from MIS 6 to MIS 2. This record documents the long-term response of the fluvial system to changes in sediment supply conditions and valley-floor geomorphology driven by Pleistocene climate change and glaciation. In contrast, the slackwater sediment record in the Voidomatis basin is much shorter, spanning a period of the order of about 15,000 years in the Late Pleistocene. This is, however, a more finely resolved record of flood history, suspended sediment source dynamics and associated environmental change. It integrates processes operating across the entire catchment without the lag times associated with inter-reach sediment transfers and long-term storage inherent in the formation of the coarse sediment record. The sediment source data from the SWDs record a relatively rapid reorganisation of the hydrology and sediment supply conditions in the catchment between about 20 and $17 \mathrm{ka}$ (Fig. 15). This reorganisation was coeval, at least in part, with the deposition of the U3 (Vikos) alluvial unit which has yielded a TL date of $19.6 \pm 3 \mathrm{ka}$. The lithology of this unit is intermediate between the cold stage alluvial units (U7 to U4) and the Holocene and modern river sediments (Fig. 7b). Marked contrasts are evident between the Late Tymphian cold stage river and the Late glacial record at Boila rockshelter which records catchment conditions when the glacial contribution is absent. The slackwater sediment archive has provided a cornerstone of palaeoflood research for more than three decades (e.g. Baker et al., 1983; Benito et al., 2003). It can be argued, however, that this archive could provide an even richer source of information on catchment response to environmental change through the wider application of the sediment provenance approach applied in the Voidomatis basin. This enhanced approach to palaeoflood studies generates a new understanding of long-term catchment dynamics that has not hitherto been attainable using conventional techniques.

\section{Acknowledgements}

We thank Geoff Bailey and all of the Klithi Project team for supporting our work in the Voidomatis basin. The three main phases of research and associated $\mathrm{PhD}$ projects in the Voidomatis basin reported in this paper were funded by the UK Science and Engineering Research Council (Woodward), The School of Geography at the University of Leeds (Hamlin) and the University of Cambridge (Hughes). The UK Natural Environment Research Council (GR9/2916 and (IP/754/ 0302) funded the bulk of the analyses reported here. The ESR work was carried out by Rainer Grün and the TL work was carried out by Nick Debenham. Uranium-series dating was carried out by Stuart Black and the NERC. We also acknowledge financial and technical support from the following UK universities: Aberystwyth, Cambridge, Leeds, Manchester and Newcastle. The authors would like to thank the organisers of the 39th Binghamton Geomorphology Symposium (Karl Butzer, Timothy Beach and Paul Hudson) for the invitation to participate in the meeting. We also thank Ken Gregory and two anonymous referees for providing helpful reviews of this paper. We would like to thank Nick Scarle (Manchester) and David Appleyard (Leeds) for drawing the diagrams.

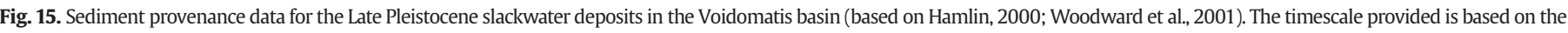

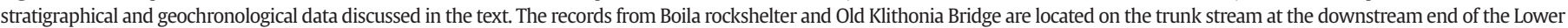

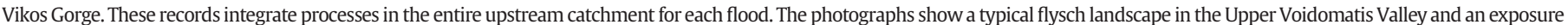

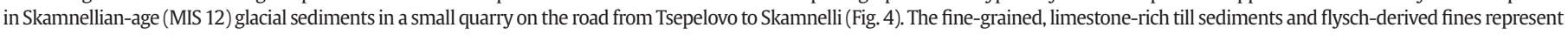
the two main sources of fluvial suspended sediment in the Voidomatis basin (Woodward et al., 1992). 


\section{References}

Baker, V.R., Kochel, R.C., Patton, P.C., Pickup, G., 1983. Paleohydrologic analysis of Holocene flood slack-water sediments. In: Collinson, J., Lewin, J. (Eds.), Modern and Ancient Fluvial Systems. Special Publication of the International Association of Sedimentologists, vol. 6, pp. 229-239.

Bailey, G.N. (Ed.), 1997a. Klithi: Palaeolithic Settlement and Quaternary Landscapes in Northwest Greece. Excavation and Intra-site Analysis at Klithi, vol. 1. McDonald Institute for Archaeological Research, Cambridge.

Bailey, G.N. (Ed.), 1997b. Klithi: Palaeolithic Settlement and Quaternary Landscapes in Northwest Greece. Klithi in its Local and Regional Setting, vol. 2. McDonald Institute for Archaeological Research, Cambridge.

Bailey, G.N., Woodward, J.C., 1997. The Klithi deposits: sedimentology, stratigraphy and chronology. In: Bailey, G.N. (Ed.), Klithi: Palaeolithic Settlement and Quaternary Landscapes in Northwest Greece. Excavation and Intra-site Analysis at Klithi, vol. 1. McDonald Institute for Archaeological Research, Cambridge, pp. 61-94.

Bailey, G.N., Lewin, J., Macklin, M.G., Woodward,J.C., 1990. The "Older Fill” of the Voidomatis Valley Northwest Greece and its relationship to the palaeolithic archaeology and glacial history of the region. Journal of Archaeological Science 17, 145-150.

Bailey, G.N., Turner, C., Woodward, J.C., Macklin, M.G., Lewin, J., 1997. The Voidomatis Basin: an introduction. In: Bailey, G.N. (Ed.), Klithi: Palaeolithic Settlement and Quaternary Landscapes in Northwest Greece. Klithi in its Local and Regional Setting, vol. 2. McDonald Institute for Archaeological Research, Cambridge, pp. 321-345.

Benito, G., Sopeñab, A., Sánchez-Moyac, Y., Machadod, M.J., Pérez-González, A., 2003. Palaeoflood record of the Tagus River (Central Spain) during the Late Pleistocene and Holocene. Quaternary Science Reviews 22, 1737-1756.

Boenzi, F., Palmentola, G., 1997. Glacial features and snow-line trend during the last glacial age in the Southern Apennines (Italy) and on Albanian and Greek mountains. Zeitschrift für Geomorphologie 41, 21-29.

Boenzi, F., Palmentola, G., Sanso, P., Tromba, F., 1992. Le tracce glaciali del massiccio dello Smolikas catena del Pindo-Grecia. Rivista Geografica Italiana 99, 379-393.

Bottrill, L.J., Walling, D.E., Leeks, G.J.L., 2000. Using recent overbank deposits to investigate contemporary sediment sources in larger river basins. In: Foster, I.D.L (Ed.), Tracers in Geomorphology. John Wiley and Sons, Chichester, pp. 369-387.

Church, M., Ryder, J.M., 1972. Paraglacial sedimentation: a consideration of fluvial processes conditioned by glaciation. Bulletin of the Geological Society of America 83, 3059-3072.

Collins, A.L., Walling, D.E., Leeks, G.J.L., 1997. Source type ascription for fluvial suspended sediment based on a quantitative composite fingerprinting technique. Catena 29,1-27.

Collins, A.L., Walling, D.E., Leeks, G.J.L., 1998. Use of composite fingerprints to determine the provenance of the contemporary suspended sediment load transported by rivers. Earth Surface Processes and Landforms 23, 31-52.

Fuller, I.C., Macklin, M.G., Passmore, D.G., Brewer, P.A., Lewin, J., Wintle, A.G., 1998. River response to high-frequency climate oscillations in southern Europe over the past 200 k.y. Geology 26, 275-278.

Giraudi, C., 2003. Middle Pleistocene to Holocene Appenine glaciation in Italy. Il Quaternario 16, 37-48

Hamlin, R.H.B. (2000) Environmental change and catastrophic flooding in the Voidomatis and Aoos Basins, northwest Greece. Unpublished PhD Thesis, University of Leeds, UK.

Hamlin, R.H.B., Woodward, J.C., Black, S., Macklin, M.G., 2000. Sediment fingerprinting as a tool for interpreting long-term river activity: the Voidomatis basin, NW Greece. In: Foster, I.D.L. (Ed.), Tracers in Geomorphology. John Wiley and Sons, Chichester, pp. 473-501.

Harvey, A.M., 2002. Effective timescales of coupling within fluvial systems. Catena 44, 175-201.

Hughes, P.D., Woodward, J.C., in press. Glacial and periglacial environments. In: J.C. Woodward (Editor) The Physical Geography of the Mediterranean. Oxford, Oxford University Press.

Hughes, P.D., Gibbard, P.L., Woodward, J.C., 2003. Relict rockglaciers as indicators of Mediterranean palaeoclimate during the Last Glacial Maximum (Late Würmian) of northwest Greece. Journal of Quaternary Science 18, 431-440.

Hughes, P.D., Woodward, J.C., Gibbard, P.L., Macklin, M.G., Gilmour, M.A., Smith, G.R., 2006a. The glacial history of the Pindus Mountains, Greece. Journal of Geology 114, 413-434.

Hughes, P.D., Woodward, J.C., Gibbard, P.L., 2006b. Glacial history of the Mediterranean mountains. Progress in Physical Geography 30, 334-364.

Hughes, P.D., Gibbard, P.L., Woodward, J.C., 2006c. Middle Pleistocene glacier behaviour in the Mediterranean: sedimentological evidence from the Pindus Mountains, Greece. Journal of the Geological Society 163, 857-867.

Hughes, P.D., Woodward, J.C., Gibbard, P.L., 2006d. Late Pleistocene glaciers and climate in the Mediterranean region. Global and Planetary Change 46, 88-98.

Hughes, P.D., Woodward, J.C., Gibbard, P.L., 2006e. The last glaciers of Greece. Zeitschrift für Geomorphologie 50, 37-61.

Hughes, P.D., Woodward, J.C., Gibbard, P.L., 2007. Middle Pleistocene cold stage climates in the Mediterranean: new evidence from the glacial record. Earth and Planetary Science Letters 253, 50-56.

IGME (Institute of Geology and Mineral Exploration) (1968) 1:50,000 Geological Map of Greece (Doliana Sheet), Institute of Geological and Mineral Exploration, Athens.

IGME (Institute of Geology and Mineral Exploration) (1970) 1:50,000 Geological Map of Greece (Tsepelovo Sheet), Institute of Geological and Mineral Exploration, Athens.

Jakucs, L., 1977. Morphogenetics of Karst Regions. Unwin Hyman, London. 284 pp.

Kelly, M., Black, S., Rowan, J.S., 2000. A calcrete-based U/Th chronology for landform evolution in the Sorbas basin, Southeast Spain. Quaternary Science Reviews 19, 995-1010.
Kochel, R.C., Baker, V.R., 1988. Paleoflood analysis using slackwater deposits. In: Baker, V.R., Kochel, R.C., Patton, P.C. (Eds.), Flood Geomorphology. John Wiley and Sons, New York, pp. 357-376.

Kotarba, A., Hercman, H., Dramis, F., 2001. On the age of Campo Imperatore glaciations, Gran Sasso Massif, Central Italy. Geografia Fisica e Dinamica Quaternaria 24, 65-69.

Kotjabopoulou, E., Panagopoulou, E., Adam, E., 1997. The Boila rockshelter: a preliminary report. In: Bailey, G.N. (Ed.), Klithi: Palaeolithic Settlement and Quaternary Landscapes in Northwest Greece. Klithi in its Local and Regional Setting, vol. 2. McDonald Institute for Archaeological Research, Cambridge, pp. 427-437.

Kotjabopoulou, E., Panagopoulou, E., Adam, E., 1999. The Boila rockshelter: further evidence of human activity in the Voidomatis Gorge. In: Bailey, G.N., Adam, E. Panagopoulou, E., Perles, C., Zachos, K. (Eds.), The Palaeolithic Archaeology of Greece and Adjacent Areas, pp. 197-210.

Lawson, I.T., Frogley, M.R., Bryant, C., Preece, R.C., Tzedakis, P.C., 2004. The Lateglacial and Holocene environmental history of the Ioannina basin, northwest Greece. Quaternary Science Reviews 23, 1599-1625.

Lewin, J., Macklin, M.G., 2003. Preservation potential for Late Quaternary river alluvium. Journal of Quaternary Science 18, 107-120.

Lewin, J., Woodward, J.C., in press. Karst geomorphology. In: J.C. Woodward (Editor) The Physical Geography of the Mediterranean. Oxford, Oxford University Press.

Lewin, J., Macklin, M.G., Woodward, J.C., 1991. Late Quaternary fluvial sedimentation in the Voidomatis Basin, Epirus, northwest Greece. Quaternary Research 35, 103-115.

Lewin, J., Macklin, M.G., Woodward, J.C. (Eds.), 1995. Mediterranean Quaternary River Environments. A.A. Balkema, Rotterdam.

Macklin, M.G., Woodward, J.C., in press. River systems and environmental change. In: J.C. Woodward (Editor) The Physical Geography of the Mediterranean. Oxford, Oxford University Press.

Macklin, M.G., Lewin, J., Woodward, J.C., 1997. Quaternary river sedimentary sequences of the Voidomatis Basin. In: Bailey, G.N. (Ed.), Klithi: Palaeolithic Settlement and Quaternary Landscapes in Northwest Greece. Klithi in its Loca and Regional Setting, vol. 2. McDonald Institute for Archaeological Research, Cambridge, pp. 347-359.

Macklin, M.G., Fuller, I.C., Lewin, J., Maas, G.S., Passmore, D.G., Rose, J., Woodward, J.C., Black, S., Hamlin, R.H.B., Rowan, J.S., 2002. Correlation of Late and Middle Pleistocene fluvial sequences in the Mediterranean and their relationship to climate change. Quaternary Science Reviews 21,1633-1644.

Messerli, B., 1967. Die Eiszeitliche und die gegenwartige Vergletscherung im Mittelmeeraum. Geographica Helvetica 22, 105-228.

Palmentola, G., Boenzi, F., Mastronuzzi, G., Tromba, F., 1990. Osservazioni sulle trace glaciali del M. Timfi, Catena del Pindo (Grecia). Geografia Fisica e Dinamica Quaternaria 13, 165-170.

Rose, J., Meng, X., 1999. River activity in small catchments over the last $140 \mathrm{ka}$, northeast Mallorca, Spain. In: Brown, A.G., Quine, T.A. (Eds.), Fluvial Processes and Environmental Change. Wiley, Chichester, pp. 91-102.

Rowan, J.S., Black, S., Macklin, M.G., Tabner, B.J., Dore, J., 2000. Quaternary environmental change in Cyrenaica evidenced by U-Th, ESR and OSL dating of coastal alluvial fan sequences. Libyan Studies 31, 5-16.

Santistebana, J.I., Schulte, L., 2007. Fluvial networks of the Iberian Peninsula: a chronological framework. Quaternary Science Reviews 26, 2738-2757.

Schulte, L., Julià, R., Burjachs, F. and Hilgers, A. (in press) Middle Pleistocene to Holocene geochronology of the River Aguas terrace sequence (Iberian Peninsula): fluvial response to Mediterranean environmental change. Geomorphology.

Smith, G.W., Nance, R.D., Genes, A.N., 1997. Quaternary glacial history of Mount Olympus. Geological Society of American Bulletin 109, 809-824.

Smith, G.R., Woodward, J.C., Heywood, D.I., Gibbard, P.L., 1998. Mapping glaciated karst terrain in Mediterranean mountain environments using SPOT and TM data. Proceedings of the 24th Annual Conference of the Remote Sensing Society, University of Greenwich, 9-11 September 1998, pp. 457-463.

Smith, G.R., Woodward, J.C., Heywood, D.I., Gibbard, P.L., 2000. Interpreting Pleistocene glacial terrains using SPOT HRV data and fuzzy techniques. Computers and Geosciences 26, 479-490.

Tzedakis, P.C., Lawson, I.T., Frogley, M.R., Hewitt, G.M., Preece, R.C., 2002. Buffered tree population changes in a Quaternary refugium: evolutionary implications. Science 297, 2044-2047.

Walling, D.E., Woodward, J.C., 1995. Tracing suspended sediment sources in river basins: a case study of the River Culm, Devon, UK. Marine and Freshwater Research 46, 327-336.

Walling, D.E., Woodward, J.C., Nicholas, A.P., 1993. A multi-parameter approach to fingerprinting suspended sediment source. Tracers in Hydrology (Proceedings of the Yokohama Symposium, August 1993). IAHS Publication No., vol. 215, pp. 329-338.

Waltham, A.C., 1978. The caves and karst of Astraka, Greece. Transactions of the British Cave Research Association 5,1-12.

Wilkinson, K.N., Pope, R.J.J., 2003. Late Quaternary alluvial processes of the Evrotas valley, southern Greece and their impact on the archaeological record. In: Howard, A., Macklin, M.G., Passmore, D. (Eds.), Alluvial Archaeology in Europe. A.A. Balkema, Lisse, pp. 187-201.

Woodward, J.C., 1997a. Late Pleistocene rockshelter sedimentation at Klithi. In: Bailey G.N. (Ed.), Klithi: Palaeolithic Settlement and Quaternary Landscapes in Northwest Greece. Klithi in its Local and Regional Setting, vol. 2. McDonald Institute for Archaeological Research, Cambridge, pp. 361-376.

Woodward, J.C., 1997b. Late Pleistocene rockshelter sedimentation at Megalakkos. In: Bailey, G.N. (Ed.), Klithi: Palaeolithic Settlement and Quaternary Landscapes in Northwest Greece. Klithi in its Local and Regional Setting, vol. 2. McDonald Institute for Archaeological Research, Cambridge, pp. 377-393.

Woodward, J.C., Bailey, G.N., 2000. Sediment sources and terminal Pleistocene geomorphological processes recorded in rockshelter sequences in northwest Greece. In Foster, I.D.L. (Ed.), Tracers in Geomorphology. John Wiley, Chichester, pp. 521-551. 
Woodward, J.C., Goldberg, P., 2001. The sedimentary records in Mediterranean rockshelters and caves: archives of environmental change. Geoarchaeology: An International Journal 16, 327-354.

Woodward, J.C., Lewin, J., Macklin, M.G., 1992. Alluvial sediment sources in a glaciated catchment: the Voidomatis basin, northwest Greece. Earth Surface Processes and Landforms 16, 205-216.

Woodward, J.C., Macklin, M.G., Lewin, J., 1994. Pedogenic weathering and relative-age dating of Quaternary alluvial sediments in the Pindus Mountains of northwest Greece. In: Robinson, D.A., Williams, R.B.G. (Eds.), Rock Weathering and Landform Evolution. John Wiley and Sons, Chichester, pp. 259-283.

Woodward, J.C. Lewin, J., Macklin, M.G., 1995. Glaciation, river behaviour and the Palaeolithic settlement of upland northwest Greece. In: Lewin, J., Macklin, M.G., Woodward, J.C. (Eds.), Mediterranean Quaternary River Environments. Balkema, Rotterdam, pp. 115-129.
Woodward, J.C., Hamlin, R.H.B., Macklin, M.G., Karkanas, P., Kotjabopoulou, E., 2001. Quantitative sourcing of slackwater deposits at Boila Rockshelter: a record of Lateglacial flooding and Palaeolithic settlement in the Pindus Mountains, northwest Greece. Geoarchaeology: An International Journal 16, 501-536.

Woodward, J.C., Macklin, M.G., Smith, G.R., 2004. Pleistocene glaciation in the mountains of Greece. In: Ehlers, J., Gibbard, P.L. (Eds.), Quaternary Glaciations Extent and Chronology - Part 1: Europe. Elsevier, Amsterdam, pp. 155-173.

Yu, L., Oldfield, F., 1989. A multivariate mixing model for identifying sediment sources from magnetic measurements. Quaternary Research 32, 168-181.

Yu, L., Oldfield, F., 1993. Quantitative sediment source ascription using magnetic measurements in a reservoir-catchment system near Nijar, S.E. Spain. Earth Surface Processes and Landforms 18, 441-454. 